\title{
JOHN WESLEY POWELL
}



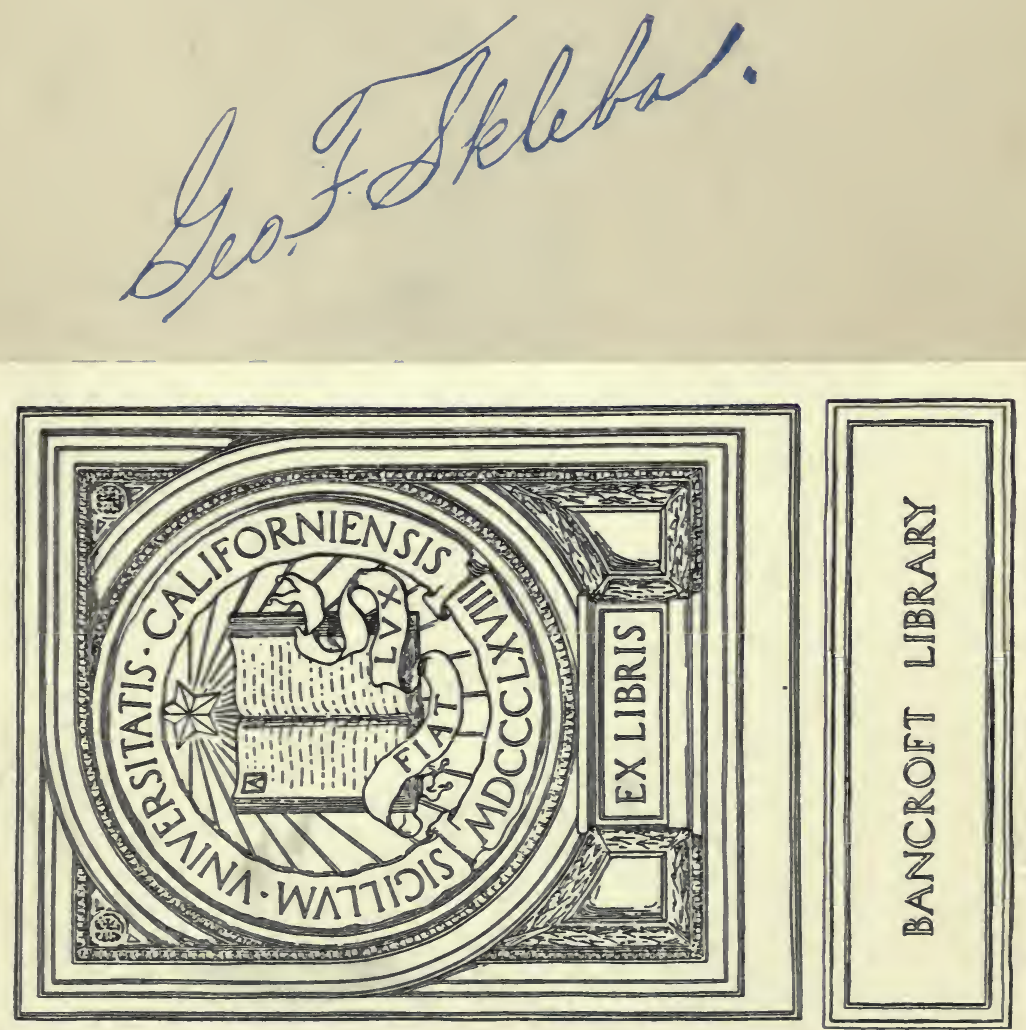


\section{BANCROFT UBRATY}

JUN 13 ฯа.? 

Digitized by the Internet Archive in 2007 with funding from Microsoft Corporation 

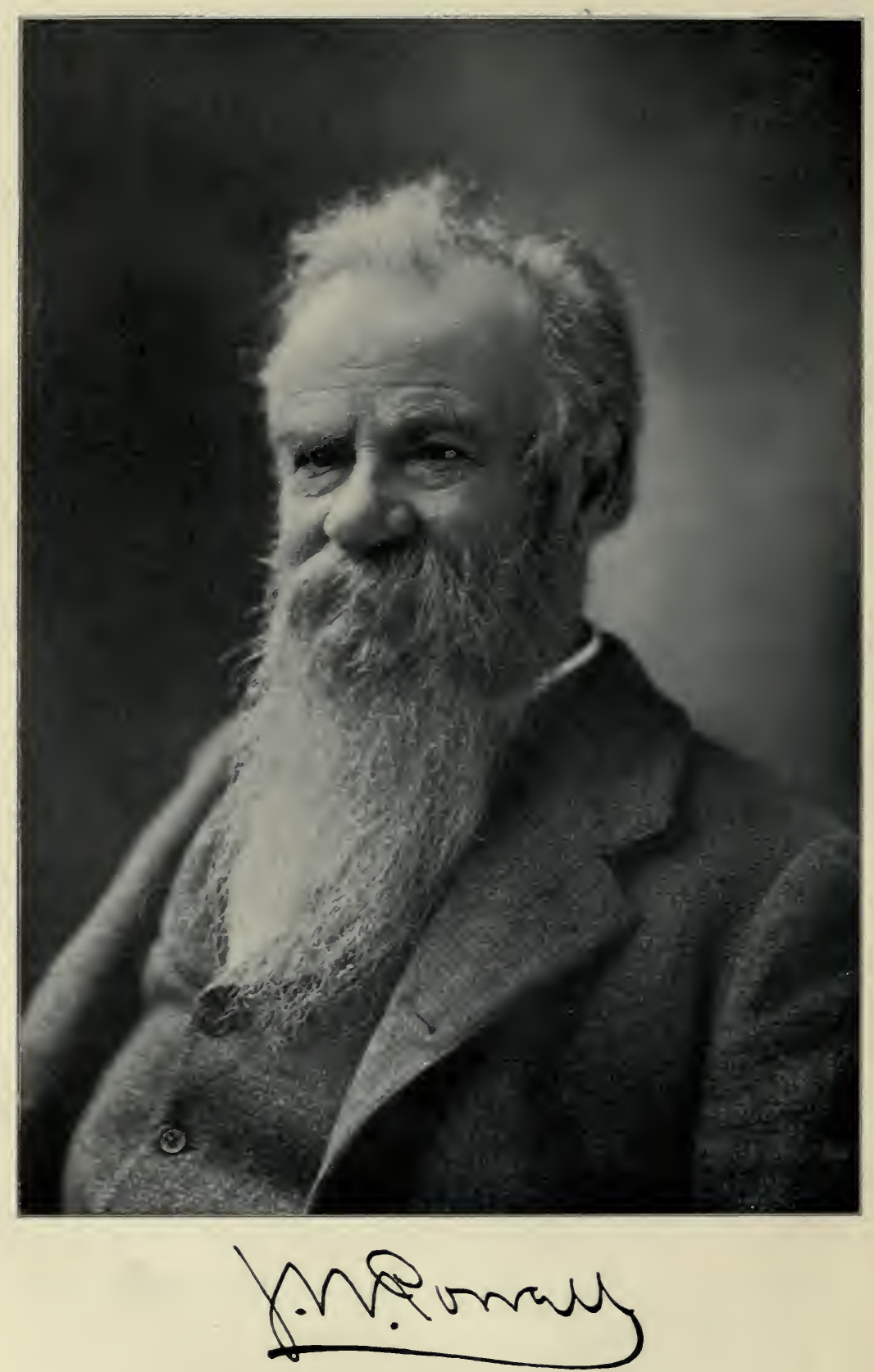


\title{
JOHN WESLEY POWELL
}

\section{A MEMORIAL TO AN AMERICAN EXPLORER AND SCHOLAR}

\author{
COMPRISING ARTICLES BY \\ MRS. M. D. LINCOLN (BESSIE BEACH), \\ GROVE KARL GILBERT, MARCUS BAKER, \\ AND PAUL CARUS
}

EDITED BY

GROVE KARL GILBERT, 1843-1918

(REPRINTED FROM “THE OPEN COURT")

CHICAGO

- THE OPEN COURT PUBLISHING COMPANY 
5594

, 9765

519186

COPYRIGHT BY

The Open Court Publishing Co.

1903 


\section{EDITORIAL NOTE.}

T N about the year 1885 Mrs. M. D. Lincoln undertook the prep1 aration of a biography of Major Powell, and from time to time during several years busied herself with the gathering of material. Her most important source was Major Powell himself, and through a series of interviews she obtained the events of his early and middle life as they were preserved in his memory. In some of those interviews she wrote down his words, and her manuscript as finally completed contains much of his characteristic phraseology. In a sense, therefore, and to a certain extent, the relation is autobiographic.

Her work covered his early life and military career, but she did not feel competent to treat of his scientific labors and attainments, and for this subject appeal was made to Mr. G. K. Gilbert, member of the Geological Survey, who wrote two further chapters on Major Powell's scientific career. This was in 1888 .

Since Major Powell's death, Mr. Gilbert has revised his manuscript so as to cover the later as well as earlier scientific work; and two chapters have been added, one by Mr. Marcus Baker, and another by the editor of The Open Court.

All these tributes to our late friend appeared in The Open Court,-December, I902, to June, I903, - and are here reprinted, with slight revision. 



\section{BOYHOOD AND YOUTH.}

JOHN WESLEY POWELL was born of English parents at Mount Morris, New York, on the 24th of March, 1834. His father, Joseph Powell, while in England, had been a preacher of the Wesleyan Church, and after reaching America he continued to preach. A diligent reader, a terse speaker, a sound thinker; honest, precise, and devout, the stern morality which he taught in the pulpit was exemplified in all his social relations and particularly in the government of his household. The severity of the father's discipline was, however, softened by the gentle influence of the mother. Remarkable alike for her womanly graces and rare gifts of mind, she shone like an angel of light in the home, planning a thousand pleasures for her children and judiciously managing her domestic affairs while her husband itinerated through the country on his ministerial labors.

Even as a child young Powell evinced his investigating tendencies. He instinctively gathered every curious shell and pebble within his reach, and read a lesson in every leaf and flower. Yet, judging from the interest he took in his Biblical studies, it would have been more reasonable to predict for him future eminence as an ecclesiastic than the brilliant career as a scientist upon which he was destined to enter. He early committed to memory the entire Gospels of Matthew, Mark, Luke, and John, much to the delight of his father. When he was about seven years of age, the family moved from Mount Morris to Jackson, Ohio. At this time the Anti-Slavery agitation was extending over the country, and in it the father took an active part. Associated with him in this work were Doctor Isham, Mr. Montgomery, and Mr. Crookham, residents of the same place. He was also on intimate terms with other men identified with the movement throughout the State, and the boy frequently saw Professors Finney and Williams, then of Oberlin College, Salmon P. Chase, afterwards Chief Justice of the 
United States, Joshua R. Giddings, and other distinguished abolitionists. To the people of southern Ohio, many of whom had originally emigrated from Virginia and other slave States, anti-slavery sentiments were extremely obnoxious. For several years an aggressive agitation was kept up; meetings were held in various portions of the State, and pamphlets in the interest of the cause were published and distributed. At one time Wesley's Thoughts on Slavery were issued in pamphlet form and widely circulated by a coterie of men living in Jackson. This publication led to a great uproar in the town, and four of the leading agitators were mobbed, and soon afterwards one of the professors of Oberlin College was assaulted on the street while on his way to the Powell residence. These years constituted a very exciting epoch in the boy's life. $\mathrm{He}$ was now old enough to appreciate the character of his father's course, and keenly felt the terrorism in which the family was constantly held.

But these circumstances led to events which profoundly influenced his subsequent life. A short distance from Jackson, on a large farm, lived Mr. Crookham, a man of some means. He had a grown family, in which were several sons who took charge of the farm and relieved their father of the cares of business. He was now an old man, and reputed to be a great scholar. To John he seemed a man of miraculous wisdom. He had built for himself two large log-houses, connected by a shed. In one he had his library, museum, and laboratory; the other was arranged as a school-house, and in this he taught gratuitously such young men as desired instruction.

As the son of an abolitionist it was at one period difficult for John to attend the village school. The boys considered that he had no rights which they were bound to respect, and his mother came to the conclusion that it was not safe for him to go to the school any longer. About this time Mr. Crookham came to see his father and mother, and the kind old gentleman proposed that John should come and study with him in his log school-house. The lad was shy and embarrassed, and it was quite a while before Mr. Crookham, although a constant visitor in the family for several years, could overcome his timidity. At last, addressing Mr. Powell, he said; "Great Britain, ${ }^{1}$ I will take the boy and make a scholar of him." To this the father consented, and that day completed the arrangements for his guardianship of the lad until the excitement should subside.

1 Mr. Crookham always called John's father "Great Britain." 
There were but three or four other pupils and their attendance was rather irregular; all but John were grown men. Mr. Crookham devoted himself largely to his own studies, especially those in natural history. With him there were no "set" lessons; he gave his pupils books to read and occasionally talked with them and asked them questions.

Within a few months, matters became quiet in the village and John returned to the common school, but Mr. Crookham took great pains to direct his reading. He brought him Hume's History of England and other nistorical works and talked with him on the subjects of which they treated. While giving him no books in natural history, he made him quite familiar with a few plants, insects, and birds, and also with some minerals, and by frequent conversations upon these various subjects, interested him in the characteristics of plants and animals, and the properties of minerals, and at the same time taught him many of the elementary facts of chemistry.

Mr. Crookham, who was a large-framed, corpulent man, often asked John to read to him, but such readings were usually interrupted by his own explanations and by general conversations, which so thoroughly illuminated the subject in hand that the boy, in his youthful imagination, came to regard his tutor as a giant of learning and benevolence. Sometimes he took John into the woods, where every step seemed to suggest something of interest. $\mathrm{He}$ would sit down on a rock, stump, or log and describe to his pupil what he had found. Naturally, as the youth grew into manhood, he looked back with great pleasure to those days, also with wonder that a man so absorbed in his books should have taken such interest in a boy so young. The old gentleman's warm friendship for the parents was not the only influence which stimulated this devotion. He saw in his protégé that genius which the father failed to discover, and watched its development with affectionate anxiety.

John's father and mother were Methodists; Mr. Crookham was a Calvinist. For hours the boy would listen to their conversations on religious subjects, and in this way acquired a good many ideas, - rather large ones; too, for one of his age,-on a variety of theological questions. He came to understand that his mother was not so entirely orthodox as his father; her opinions were perhaps slightly tinted with Swedenborgian mysticism. Be that as it may, her theology seemed to his boyish perceptions a great deal better than that of his father or Mr. Crookham. When the two were discussing their relative opinions, it was John's habit to wait 
for and expect his mother's final exposition of the subject. He thoroughly believed that she knew exactly the truth, and he used to wonder why the men argued over these matters so long, and why they did not at the outset ask his mother to explain to them just what was right.

One day the old Calvinist came puffing up the steps of neighbor Powell's house, walked through the sitting-room, and sitting down in the kitchen where John's mother was busy, asked for "Great Britain." He was evidently greatly agitated, and after a time explained that some rowdies had burned his school-house, library, and cabinet, and that all was lost. He seemed not to care so greatly on his own account, but to mourn chiefly because the means with which to teach his "youngsters" had been destroyed. After that he came more frequently to his father's house, and if possible took more minute direction of the boy's studies. Although by reason of the latter's extreme youth, it was scarcely to be expected that he should have made great advance in natural history, yet the two or three years thus spent under the guidance of Mr. Crookham were of real importance in giving to his thoughts that inclination which carried him eventually and permanently into the profession of science and of letters.

During these years, it had been the father's ambition to place his family in such a position that they could live comfortably, and to devote himself exclusively to the ministry. Finally, when John was twelve years old, Mr. Powell moved further west, making the journey across northern Indiana, through Chicago, to Walworth County, Wisconsin. This was accomplished with an emigrant wagon loaded with household goods, and two carriages, one of the latter being driven by John. His father had previously bought some land, but upon reaching it decided not to settle on it, but to purchase a partly improved farm. The next summer he commenced preaching regularly, leaving the Methodist Church, however, and joining the Wesleyan, on account of his anti-slavery sentiments. He knew nothing about farming, did not work on the farm, and took no part in its management. All this devolved upon John, and, aided by two or three farm employees, the schoolboy became a farmer, with all the responsibilities of the position, heavy indeed for a lad of his years.

The farm was in burr-oak woods, and but a small tract was cultivated the first year. During the second winter a large area was cleared and fenced, and in the course of a few years about sixty acres of land were brought under cultivation. John worked 
continuously summer and winter: clearing the land, sodding, ditching, ploughing, planting, building, adding an annex to the house and making the barn larger, constituted only a small part of the work planned or executed. He labored through the long days and studied far into the night, eagerly perusing all the books he could procure.

Following the plough did not suit him. While he turned the soil, his thoughts were far away amid the rocks and woods of his old home, where Mr. Crookham first opened the volume of Nature to his wondering eyes. Yet he toiled faithfully. His home was fifty miles from what was then called Southport (now Kenosha), and sixty miles from Racine, and these places were the markets of the country. In the late fall and early winter months his time was usually occupied in hauling wheat to one or the other of these towns. With the money obtained from the sale of grain he had to make the purchases for the family,-groceries, clothing, lumber, and such other things as were needed on the farm. It was a five or six days' journey, and from twelve to fifteen trips were made each year. Those were the pioneer days of our country, when oxen drew the plough and hauled the produce of the farms to market. Southern Wisconsin was at that time a great wheat-producing region, and all farmers in the country were on the road during the fall and winter. He did not then realise how perilous was the promiscuous company of travellers in his goings to and from the market towns in these years of his life. He was associated with hardy, jovial, and often very hilarious frontiersmen, and there were temptations on the road and in the city to which a country boy might have readily yielded. But there were circumstances which protected him from the bad influences by which he was surrounded. He had a sense of great responsibility, especially so because the family purse was in his custody. His father and mother so completely trusted him that they never asked him to account for his transactions.

In one of the earlier years of his pioneer life, he fell in company with one William Wheeler, several years his senior, who took great interest in him, and whom the boy, recognising as a superior, soon came to regard with sincere esteem and affection. Mr. Wheeler said nothing about morality, but his general conduct and noble example were such as to make a deep impression on the lad. He was far superior in education to his young companion, - had at one time been in college and now occupied himself very much in reading, letting his team follow the others while he poured over 
some entertaining volume. John was quick to follow his example. His wagon-box became a receptacle for books, and while his reading was desultory, it was nevertheless valuable. Histories and biographies pleased him the most. On these trips he re-read Hume's History of England, Gibbon's Rome, a history of the United States, and finally Dick's philosophy and some works in - Mental Philosophy. He never read a work of fiction or a volume of poetry, although his mother had frequently urged him to read Milton. Now he became interested in Bunyan's Pilgrim's Progress, and no matter what other books he selected for companions on these long journeys, that one was sure to be found in his wagonbox, for he could read it when he was tired of all others. He never, by the way, considered Bunyan a work of fiction.

In the winter of 1850 , when he was sixteen years old, his discontent with farm work impelled him to leave home, and he went to Janesville, determined to attend school. Janesville was about twenty miles distant, and he walked the first day to a farmhouse within about two miles of the town. He had but a few cents in his pocket, and stopping at the farmhouse to stay over night, he asked for work. The farmer engaged him for two weeks, and at the end of that time, with six dollars in his pocket, John proceeded to Janesville and visited the school. He returned to the outskirts of the town and made arrangements with a farmer to work nights and mornings for his board, stipulating that he should have his time during school hours for study.

The family lived in a log house. John's business was to feed and water the cattle and sheep, and to care for them generally; and, at night, after his work was done in the farmyard, he sat by the chimney-side rocking the cradle and studying his books by the fire-light as best he could. The next year Joseph Powell sold the farm at South Grove and moved to another on Bonus Prairie, in Boone county, Illinois.

In the fall of 1852 , when John was eighteen, it was decided by his mother that he should commence his school life. The first thing to be done was to earn the necessary money. Early in the month of October he put the farm in as good shape as possible and turned it over to his younger brother, W. B. Powell, and commenced studying at home. For six weeks his school was in the garret, where he remained almost day and night, studying grammar, arith . metic, and geography. He then set out for the southern part of Wisconsin, about thirty miles distant, and had no difficulty in securing engagement as a teacher. The school engaged, the next 
task was to procure the necessary certificate of proficiency. One day in the latter part of November he went to the township superintendent to be examined. A feeling of dread possessed him lest he should fail on examination.

As he approached the Superintendent's house a fierce wind blew the snow in his face. All aglow with the excitement of a walk of twenty miles in a sharp gale, he knocked at the door. The lady of the house, with a cheerful reassuring voice, invited him in, but he had to wait two or three hours for the return of the Superintendent. At last he came, and insisted that John, now the dignified School-Master, Mr. Powell, should stay all night. As the family sat together at the supper table, the Superintendent conversed with the young man about the school he was to teach, and about various subjects that would engage his attention, in so kind and skilful a way, that during the evening he drew out such knowledge as his visitor possessed without giving him an idea that he was passing the dreaded ordeal. Just before going to bed, and greatly to the surprise of his visitor, he filled out a certificate, signed it and handed it to the young man. The superintendent was a man of fine culture; his advice was always good, and during the winter he gave the young teacher much valuable aid.

The school over which Powell was to preside was on the north side of Jefferson Prairie, and a little stone school-house was his first college. At least half of his pupils were older than himself, and several of them were quite as far advanced in their studies. This compelled him to work very hard, and certainly no pupil in the school made such progress as did he. He provided himself with several school arithmetics and worked through them all. $\mathrm{He}$ studied elementary algebra, and took the class about half as far as he went himself. He read three or four grammars, and made decided progress in geography, and on this subject gave a lecture one night in the week to the most advanced pupils. The other young people of the neighborhood, as well as pupils from adjoining towns, came to these lectures. For this work Powell prepared himself by systematic study and vigorous consultation of books of reference; he also made excellent use of his limited knowledge of history, weaving it deftly into his account of the lands of the world.

By contract the teacher was to "board around," but one of the trustees, Mr. Little, took Mr. Powell to his home and insisted that he should stay the greater part of his time with him. His wife had been a New England school-teacher, and she had what seemed to the young man a marvellous library. She took great interest in his 
geographic work and always kept him supplied with abundant material from which to prepare his lectures, and he always gave her an outline of his discourse before delivering it in public.

In the following summer ( 1853 ) he worked on a farm at Bonus Prairie. In the meantime his father became interested in the founding of a school at Wheaton, Illinois, under the auspices of the Wesleyan Methodists. Near the village he bought a small tract of land of forty acres, on which stood a little farmhouse. He had also bought five acres of land close by the new building erected for college purpose, and was himself one of the trustees of the college. Early in the fall John's mother and sister journeyed with him from Bonus Prairie to Wheaton. On reaching that place he had the little frame moved from the forty-acre lot to the five-acre lot near the village, a distance of about half a mile, and with the help of two or three men it was soon fitted up in comfortable style for the winter. Here John studied and taught until summer, when he returned to the farm.

Early in the fall of 1854 he went south to Macon County, and taught a County school, and the following spring went into business with his brother-in-law, Mr. Davis, who had married his eldest sister. A nursery and stock farm, the latter for sheep, was the business venture in which he engaged, hoping that at the end of two or three years he would make sufficient money to enable him to take a college course.

When the news of his undertaking reached his father, and with it the alarming statement that John had run into debt, he wrote his son a very bitter letter, saying that he considered the debts which he had assumed to be dishonorable and that his course in the matter was not a whit better than highway robbery. His mother also wrote advising him to withdraw from the business, although she treated the matter with leniency. The combined opposition of his parents made him relinquish the enterprise, and he then fully determined never to commence again until he had completed a course of study. Accordingly he went to Decatur and rented a little house with a single room, which had previously been used as a shoe-shop. In this humble tenement he boarded himself, purchasing bread, milk, and such other things as did not need cooking; and occasionally his sister, who lived in the country, would send him a joint of meat ready for the table, or would in other ways add to his little store.

On going to Wheaton, he expected that the school would furnish all the educational facilities needed, but as it was just or- 
ganised he soon found himself in advance of any of its classes. He then formed the resolution of studying by himself. The persevering and indomitable student may not have judiciously selected his studies; but his work in algebra, geometry, and trigonometry was successful and satisfactory. His studies in mental and moral philosophy and his general reading in history were less profitable, perhaps; but his progress in Latin compensated for the deficiency.

During the winter of 1856 he taught school in Clinton, De Witt County, Illinois, and received sixty dollars per month. At the little stone school-house he had received fourteen dollars per month, and in the school near Decatur, thirty dollars per month, and his increased salary of sixty dollars per month seemed to him a large amount. The next year he attended classes in Jacksonville College, Illinois, studying Latin and Greek, reviewing trigonometry and attending lectures in chemistry.

His father had always desired that his son should go to Oberlin, and at last in deference to that strongly expressed wish, he entered Oberlin College in 1857 . Being far advanced in the scientific branches of study, he now devoted himself chiefly to Greek and Latir, studying botany also during the spring term. There was no winter school at Oberlin at that time, as the faculty believed the interests of the pupils were subserved by a vacation which would enable them to teach during the winter months. Consequently Mr. Powell returned to Wheaton, entered school there, and remained a year. During all this time his studies had been irregular, but he was in a position where he could graduate in any western college by a few months' application.

For several years he had given all his attention to botany and zoölogy. He had an herbarium of many thousand plants, and a large collection of lacustrine river and land shells, and quite a large cabinet of the reptiles found in Illinois, Iowa, and Michigan. One spring day he went through the village of Wheaton with a basket containing some glass fruit-cans, to be used as specimen jars, on his way to the woods for the purpose of collecting snakes. As he passed a group of men they asked him where he was going. His reply was that he needed another rattlesnake in his collection. As it happened he found a rattlesnake that day, and on his return through the village at night, with the live reptile in a glass jar, he chanced to meet the same gentlemen with whom he had been talking in the morning. This mere accident led to a curious and rather fabulous story, to the effect that he was acquainted with the homes of all the animals, knew their habits, and could at any time find 
any animal he desired. This reputation clung to him for years; the incident got into the country papers and was repeated until the story became greatly exaggerated. When last repeated, the young naturalist learned for the first time that he had appropriated the upper story of his father's house for a museum, and had it full of all sorts of reptiles; and that he could go to the woods and fields any day and find any reptile, mammal, or bird that pleased his fancy, and that he lived in a house full of them and was constantly employed in studying their habits. To be sure he had a large collection, and was very familiar with it ; but the story was much larger than the collection.

About this time he was probably more interested in mollusks than in any other department of natural history. He had a very large collection made by himself from the Great Lakes, the small interior lakes of Wisconsin and Illinois, the Mississippi River, and from most of the rivers of Iowa, Illinois, Missouri, Indiana, and Kentucky, besides a good representation of the land shells of all that region of country. His greatest difficulty was in obtaining books to enable him to identify species. There were many specimens which he was never able properly to identify, but he gave them names according to the locality where they were collected, and from the characteristics of the shells. He had collected some fossils, also, and had studied minerals sufficiently to become familiar with the use of the blow-pipe.

During the summer of this year he continued his travels, especially along the Ohio River and across to the lakes, and then through Michigan. In the fall he went to the Iron Mountain region, south of St. Louis, Missouri, for the purpose of collecting minerals. He found the country so interesting that he continued his stay in the field until he barely had the funds necessary to take him to St. Louis, where he hoped to earn enough to pay his expenses home. Not finding work at once, he pawned his watch and went to Decatur where he had previously lived. Later he engaged to teach at Hennepin, Illinois, and continued teaching for six months, receiving one hundred dollars per month.

It was his intention at the time to earn a sum of money sufficient to enable him to study in some Eastern college one or two years and graduate, but when the spring time came the old fascination for natural history studies predominated, and he made geology a specialty.

The town of Hennepin standing on a bluff of the Illinois River, was of itself a study. The underlying country for miles around 
was a deep accumulation of drift-like material. A great valley or basin had been filled and the carboniferous rocks which came near the surface were here marked to the depth of about two hundred feet. During the winter Powell became greatly interested in this body of drift material and the peculiar characteristics of the country, and early in the spring he commenced a more thorough examination of it and the adjacent county of La Salle. He devoted several weeks to this work, and then extended his examination farther and farther away, up and down the valley of the Illinois, and finally through the valley of the Mississippi and along the Des Moines River in Iowa and thénce into southern Wisconsin.

His geological studies interested him deeply, and he continued out late in the fall. On returning to Hennepin he decided to teach again and postpone for another year his trip to the East. During these scientific trips he had formed the acquaintance of many scholars interested in natural history and geology, and was elected Secretary of the Illinois Natural History Society. In this capacity, and through the kindness of many devoted friends, he was enabled to journey, by rail or boat, for several years, without expense ; and being a good walker, his expenses as a travelling student were always trivial. He could sleep at night on the ground under a tree with impunity, for he had perfect health and was an athlete.

Thus young Powell's student days were not all passed in the school-room, though he had diligently applied himself to study under the direction of various teachers. Much of his study was made privately, as he was impelled by a desire to acquire material for successful instruction. The teacher thus became the more careful student. To a large extent his school-room was in the forest and the field, on the prairie and the mountain, and along the river bank and the lake shore; for he early became a student of nature, and studied in the solitudes of nature. 


\section{THE SOLDIER.}

T the winter of $1860-1861$, our devoted and successful young I scientist was teaching school for the second year at Hennepin. Of fine physique, commanding respect everywhere by virtue of his mental acquirements and natural endowments, a sound, earnest thinker, it is not strange that when Abraham Lincoln issued his call for 75,000 troops, this stanch abolitionist should immediately organise a company of soldiers. Some days later a company at Granville was accepted by the Governor as one of the companies to constitute the twentieth regiment of Illinois Infantry. With the small party assembled at Hennepin John Powell went to Granville and joined the Granville Company as a private soldier.

Vividly the days of childhood came back to him, and the antislavery sentiments which he had inherited and which were fostered by his father's teaching and daring example, made him enlist for a purpose higher and greater than the glory of martial triumph. $\mathrm{He}$ enlisted with the avowed purpose of doing his part in the extinction of slavery in this country; and from the first day after the call was made for troops, he felt thoroughly convinced that American slavery was doomed. $\mathrm{He}$ found reasons later in life for enlarging his opinions regarding the importance of the issue at stake; for he says in a letter to a friend:

"It was a great thing to destroy slavery, but the integrity of the Union was of no less importance : and on and beyond it all, was to be counted the result of the war as an influence which should extend far into the history of the future, not only establishing in North America a great predominating nation, with a popular and powerful government; but also as securing the ascendency of the Anglo-Saxon branch of the Aryan family, and the ultimate spread of Anglo-Saxon civilisation over the globe. Perhaps it is only a dreamer's vision wherein I see the English language become the language of the world; of the science, the institutions, and the arts of the world; and the nations integrated as a congeries of republican states." .

The eradication of slavery and the preservation of the Union, were, he believed, the important epochs in the course of history 
which would lead to these results; and he carried the musket to help as best he could to secure the fruition of what he saw in prophetic vision. And thousands more saw the shadow of fulfilment as the scathing fire mowed them down.

When the Twentieth Illinois was organised at Joliet, our hero was made the Sergeant-Major of the regiment. At the end of the month, when it was mustered into the United States service, he was commissioned as Second Lieutenant. Before the regiment was mustered, and while he was still Sergeant-Major, he obtained permission of its Colonel to go to Chicago, which was only sixty miles distant, on a plea that he desired to purchase a uniform. His main object, however, was a desire to obtain some books on military science, and while in Chicago he obtained Mahan's and Vauban's works on military engineering. He returned to Joliet, where the regiment was still stationed. These books, together with a small volume of Tactics and the Army Regulations, furnished study for some weeks, and whenever possible he went some distance away from camp for the purpose of looking over and studying topographical features and planning military works for the defense. The Lientenant-Colonel of the regiment, who was subsequently killed at Donaldsonville, finding the Lieutenant studying military science, would sometimes join him, and they often had discussions about military works, such as entrenchments, fortifications, and bridges. Civil engineering and the construction of bridges had been previously studied by Lieutenant Powell.

When finally the regiment was ordered into the field at Cape Girardeau, Missouri, the Colonel of the regiment directed Lieutenant Powell to look over the ground, select a camp, and prepare a plan for the entrenchment of the camp; and his orders were satisfactorily carried out. At Cape Girardeau there were four regiments commanded by C. C. Marsh, the Colonel of the Twentieth Illinois Infantry, to which Lieutenant Powell belonged. During the first week of the occupation of Cape Girardeau, he carefully studied the country about the camp and made a map of it, and prepared a plan of works for the defense of the town, should it be necessary; but no work was done in the field to carry out this plan, until one day General Fremont arrived at Cape Girardeau with a large retinue of foreign officers, and informed Colonel Marsh that he desired to have the city fortified. Colonel Marsh sent for Lieutenant Powell and asked him to submit the map and his plan to General Fremont and his staff. They approved his plan and Colonel 
Marsh was ordered to prosecute the work with the greatest possible vigor.

The summer, fall, and winter were occupied in carrying out his order. At one time a Prussian officer was sent by General Fremont to take charge of the work, but as he could not speak English and was a very old man, he occupied himself in the construction of a small fort which could perhaps cover three or four hundred men at most, and Lieutenant Powell went on with the construction of a system of works inclosing the city.

After a time, Captain (afterwards Colonel) Fladd, who had been engaged on the works at St. Louis, and was an accomplished engineer, came down and took charge, and he made Lieutenant Powell his assistant, a good school of engineering for the young lieutenant. Altogether the works were on an extensive scale, and many thousand men were employed. When General Grant took command, some time in the early winter, the operations of this character were limited to the completion of a part of the work already under way; and the entire plan was never fully executed.

One day General Grant came up from Cairo to inspect the works, and Lieutenant Powell rode with him two or three hours; and after the ride was over he invited the young soldier to take supper with him on his boat. - After supper, Lieutenant Powell said to the General that he desired a leave of absence for one week, and frankly told him that he had been engaged to a young lady in Detroit for a long time, and that he wished to go home to get married, and would return in a week. The General gave him the leave of absence; he went to Detroit, arrived there about six o'clock in the evening, was immediately married to Miss Emma Dean of that city, and started on the train at eight o'clock with his bride on the return to Girardeau.

Their wedding journey was to the Seat of War in the southwest, a moveable grand division, with its "headquarters" as apt to be in the saddle as in the fields of Kentucky or Tennessee; it then being under the leadership of that great Captain of the culminating victory who in taking Fort Donaldson, introduced to the world the leaders of the waiting hosts east and west.

Not a very delightful situation this for a "honey-moon"-but Mrs. Powell had heroic blood in her veins, and she followed the army without hesitation, bearing the inevitable inconveniences and privations of camp-life with womanly fortitude; one of the ways in which the sex stimulated the other half of the world to do their duty as men, and show their own valor through privations and 
waiting-sometimes harder to endure than being in the midst of the battle.

Lieutenant Powell was on General McPherson's staff; within a month after his marriage he lost his right arm at the battle of Pittsburgh Landing or Shiloh.

General Grant was again at Cape Girardeau and Lieutenant Powell, who then was on General McPherson's staff, begged that he might be relieved from duty at that point as engineer, and ordered back to his regiment, which was then at Bird's Point. To this the General would not consent, but shortly after sent him a commission as Captain of Artillery. It seems the General had written to Governor Yates, telling him he did not wish Lieutenant Powell to return to his regiment, and that as the State of Illinois was organising batteries of Artillery, he thought Lieutenant Powell could make up a battery with some Missouri soldiers that were there, and who had been enlisted without authority from Washington, under instructions from General Fremont, and that if Governor Yates could send a few men from Illinois, they would be put together in this battery.

When Lieutenant Powell received this commission, he was instructed to take the Missouri soldiers who were camped outside of the city of Cape Girardeau, together with some men sent by Governor Yates, and with them organise under his command as their captain the company which was afterwards known as "Battery F, Second Illinois Light Artillery."

While stationed at Cape Girardeau, the troops on two occasions were sent into the interior of Missouri to operate against Jeff. Thompson. On two occasions Captain Powell went with them as staff-officer, his principal duty being to study the country and give information of routes and to construct maps of the region to be travelled.

In the latter part of the month of March, 1862 , he was ordered to the Tennessee River.

In his six weeks' experience with the Twentieth Illinois Infantry he paid close attention to the study of tactics, and as the Lieutenant of Company $\mathrm{H}$ of that regiment he became a good drill. master. When the battery was organised he manifested great interest in artillery tactics, and became proud of the performance of his battery on drill and parade. Full of activity, with zeal not always characterised by the wisdom which more deliberate men would have advised, he was a severe and almost unreasonable disciplinarian, drilling his men on every possible opportunity. When 
the battery went up the Tennessee, it had I 56 stalwart men; and a finer lot of horses was never, perhaps, attached to a battery. Although this company had been organised but a few weeks, it went into park on the bluffs above Pittsburgh Landing, a grand body of men, well drilled, and with an equipment complete and in the best possible condition.

A week later everything was sadly changed. It was within a month of the young captain's marriage that the battle of Shiloh or Pittsburgh Landing took place, and in it his battery played an important and heroic part. Most of the horses were lost, many of the men were killed, still more wounded, and Captain Powell had his right arm shot off.

[Capt. Powell was crippled for life, and the stump of his right arm was subject to incessant pain until in his advanced years, I believe in 1898 , a successful operation on the terminating nerves gave him relief; and henceforth he felt as if he had been regenerated and had received back his original vigor.

In connection with the loss of his right arm, I wish to record an incident which is typical of American conditions. In the same battle of Shiloh, a Southern officer, Col. Charles E. Hooker, afterwards Member of Congress from Mississippi, lost his left arm, and after the war the warriors met and became friends. It happened that their hands were of the same size, and henceforward whenever either purchased a pair of gloves he sent the unnecessary one to his enemy; the two veterans ever after remained friends. $]^{1}$

The officer left in command probably could not muster more than half of the number that had gone up to Pittsburgh Landing. His [Captain Powell's] young wife was on the field-at headquarters-when he was wounded, and she then and there enlisted for the war, General Grant giving her a "perpetual pass" to follow the army and thus enable her to act as right arm for her husband. Otherwise he would have had to leave the service, and that would have been a great loss, as his skill as an engineer and artillerist ranked high; and General McPherson relied upon his knowledge most implicitly; placing him always-with his dogs of war-in the most responsible positions.

Mrs. Powell nursed her husband back to life in the hospital; and he did not hesitate to say that he believed he "owed his life to his wife's presence, fortitude, and unwearied devotion, united to her skilful nursing."

In the summer of 1862 the captain returned to the command

1 The passage in brackets was inserted by the editor, on the authority of Major Powell. 
commanded the Fourth Division of the Seventeenth Corps. One or two regiments of the division were away at the time. Three batteries were under Capt. Powell's command, and to get these across the peninsula, through the mud and over bayous, was a somewhat difficult task. He had to build many bridges and corduroy many miles of road, a work necessary not only for the battery but for the whole division, and for trains that followed in the line of the troops. At last, when the division had reached Grand Gulf and pushed back into the interior of the State of Mississippi to Jackson, Johnson's army having been driven eastward from Jackson, General Grant turned back toward Vicksburg in order to meet General Pemberton. On the march toward Vicksburg, Captain Powell took part in the battle of Champion Hill and that of Black River Bridge.

An incident worthy of note occurred at the battle of Champion Hill. When Captain Powell enlisted in Company $\mathrm{H}$ of the Twentieth Illinois Infantry, he took with him some of the men who had agreed to join his company at Hennepin, to fill out the company organised at Granville. One of these men was a tall Scotchman by the name of Morgrave, brave and trustworthy as a soldier as he had been respected and valued as a private citizen. At the battle of Champion Hill, Morgrave, who was then a non-commissioned officer in the Twentieth Illinois, was sent to the right of the Twentieth to reconnoiter.- There was a body of troops on the right, and the colonel of the regiment was uncertain whether they were Union or Confederate soldiers. Morgrave went out and fell into the hands of the enemy. Fighting soon began. The soldier in whose charge Morgrave was placed told him to lie down under a log, and the guard lay down by him. Soon the enemy gave way, and the Union troops passed over the ground, driving the Confederates back. As they lay behind the fallen tree, the movements of the troops were uncertain to the hiding party; but finally Morgrave concluded that he had as much right to the position as his guard. Laying his hand upon the gun, he called upon the guard to surrender; and the guard surrendered. Neither party yet knew who were victorious, the Confederates or the Union troops. A few moments after this, Captain Powell chanced to be riding over the ground for the purpose of bringing up the battery that was in the rear, and he saw Morgrave and his man. They called to him, and Morgrave in great earnestness asked which of the two should be considered the prisoner. When informed of the result of the battle, he was much delighted. 
After the battle of Champion Hill, General Pemberton's army was driven across Black River, and the bank of the river was occupied by the Union troops. About two o'clock in the afternoon the railroad bridge was burned by the enemy, and bridges had to be built immediately. During that afternoon and night they were constructed across the river, and by daylight two divisions had crossed on this bridge, including the batteries which he commanded.

For two days they fought their way toward Vicksburg and on the 2Ist of May invested the works that sheltered General Pemberton. During the night of the 2Ist Captain Powell was occupied in arranging the lines of the division to which he belonged (Ransom's division), and in getting the batteries into position under cover of rude and hastily constructed earthworks. On the 22nd a severe engagement occurred; and on the 23 rd the siege operations fairly commenced, and he was engaged in them, day and night, from that time until the fourth of July. In no other forty days of his life had he ever worked so hard. It was his custom to lay out the works at night, and to direct the digging by the troops; and during the day he was engaged in preparing materials.

The work consisted chiefly in running parallels, and in constructing batteries and defensive works for the artillery. The ground was covered with fallen trees through which a dense jungle of cane was growing. This cane was cut and used in making fascines and other materials used in the construction of gabions to be employed for revetment. On the evening of the 22nd, while engaged in laying out work of this kind, one of his soldiers suggested that the telegraph wire could be used for binding the fascines, and at night nearly three hundred men were set to work making fascines and tying them with wire, the rude machinery for this being devised upon the spot. The telegraph wire ran towards Jackson from a point which was occupied by Ransom's division, and gradually this wire for many miles back was brought in to be used for this purpose.

The hills about Vicksburg are composed of loess, and this material was of a character well adapted to their purposes. They ran long galleries in it without any support, and they soon had a system of galleries extending quite under the enemy's guns, and their own troops were gradually brought up by a system of parallels to the very ditches of the enemy's main works. All the enemy's salients were abandoned quite early in the siege, and the Union guns were so arranged that they would enfilade every rod of his breast- 
works; and for several days before the surrender no man could safely show himself above the works of the enemy.

On the third of July, General McPherson rode up near where Captain Powell was at work and sent for him, and soon after General Ransom came up, and General McPherson asked General Ransom if he thought the works could be successfully stormed from his (Ransom's) front; Ransom believed they could, and the details of the movement along that route were then explained and agreed upon; but just when it should take place was left uncertain. General McPherson thought it would probably be at daybreak on the morning of the fifth, but that circumstances might demand that it should be made sooner, and expressed a desire that General Ransom should be prepared to move at any time. After consultation the generals went away. A few minutes later General McPherson returned, and taking pen and ink from an orderly he wrote an order for Captain Powell to have the batteries open upon the enemy's line, with a national salute at daybreak on the morning of the fourth. At daybreak, however, the enemy had surrendered, and instead of firing a national salute the Union troops moved forward a few yards over the enemy's works and took possession of his lines.

Two or three days after, McPherson was informed that the enemy was crossing a large body of horses and cattle over the Mississippi at Natchez, and General Ransom was ordered to take boats, descend the river, and capture the cattle if possible. Natchez was soon reached, and on landing Ransom's division was hurriedly run into the country, and a large district including the city of Natchez was surrounded with troops. The line was gradually concentrated as it moved toward Natchez, and within the circle some hundreds, perhaps thousands, of cattle were enclosed. Some of these cattle were speedily sent to Vicksburg, and orders were soon received to take others to New Orleans and supply General Banks's army.

Captain Powell went down with the troops to New Orleans, and on returning to Natchez he obtained a leave of absence. During the siege of Vicksburg the excessive work had greatly reduced him in flesh, and in addition to this his arm had given almost incessant pain. After a consultation of the surgeons it was decided that he should have a resection, and for that operation he preferred to go home. During all the campaign up to that time his wife had been with him, and they went together to Detroit, where the operation was performed.

He soon recovered, and in the fall returned to Natchez, where he found General Crocker of Iowa in command, General Ransom 
having been ordered to report to General Banks. General Crocker remained in Natchez a few weeks after Captain Powell's return, and then was ordered to Vicksburg, and finally back of Vicksburg to a little place called Hebron, where winter quarters were established. Captain Powell had their batteries parked on a beautiful piece of ground, barracks were constructed for the men, and stables erected for the horses, and the weeks were spent in recruiting men and horses and preparing for more active operations.

Then the expedition to Meridian was made by General Sherman, and the division to which Captain Powell was attached took part. The movement was one of destruction, its purpose being to attack a small body of troops which had occupied the country not far from Jackson, drive them across the State of Mississippi and back into Georgia, and destroy all railroad communication with Vicksburg, in order that the captured city might be garrisoned with a small force, and the main body of the army withdrawn to take part in operations elsewhere.

In the march to Meridian the army met with but little opposition; from day to day there was skirmishing, and some loss of life on both sides, but the railroads over a broad zone of country were torn up, and everything that could be utilised by an enemy in support of troops was destroyed. This destruction often involved the burning of farm-houses and barns, and many buildings were reduced to ashes. On the return a vast horde of negroes, men, women, and children, with horses, mules, and cattle, were brought back from Vicksburg, and once more General Crocker's division went into camp at Hebron.

Early in the spring his division was ordered to Chattanooga, but in the meantime a regiment of colored troops was partly organised at Vicksburg, and Captain Powell, upon the request of General Thomas, consented to take charge of them. He soon came to the conclusion that these troops were not likely to take an active part in the war, but would probably be held behind for garrison duty; so he determined not to be mustered in as colonel of the regiment, though a commission had been sent him, and he obtained permission to join the Fourth Division once more.

On his return to the Fourteenth Division he was made Chief of Artillery, of the Seventeenth Corps, having previously been commissioned as Major, and took part in the operations around Atlanta. Subsequently he was made Chief of Artillery of the Department of the Tennessee.

When General Hood turned back toward Nashville, Major 
Powell was with the pursuing army under Sherman, and was with him on Kenesaw mountain when General Corse was attacked at Altoona. Having driven Hood westward towards Rome, General Sherman turned back towards Atlanta once more, and went on beyond Jonesboro. A day or two before the railroad communication was broken with Nashville General Sherman concluded that the artillery could be moved across to Savannah. During the campaign there was great loss of horses, and the artillery was using old horses and mules to slowly drag the pieces over the country. Sherman deciding that all these animals were necessary for the quartermaster's train, Powell was ordered to take sixteen batteries of the Army of the Tennessee back to Nashville and ship them around to Savannah. He reached Nashville with the batteries just before the battle of Franklin was fought, and received instruction from Washington to report to General Thomas. Thus it happened that he participated in the battle of Nashville.

For some days before the battle, he was busily occupied in superintending the constructions of defense. On the morning of the battle, under General Thomas's instructions, he had the sixteen batteries under his command arranged in four divisions and distributed at as many different points along the rear of our army. From time to time, as the battle raged, these batteries were sent to the front under orders from General Thomas, and engaged in the conflict. Major Powell, riding from point to point, occasionally returning to General Thomas for further instructions, was for the first time during the war witness of an entire battle; that is, he was able to comprehend the operations on the various parts of the line, and to see the most important engagements on the first and second day.

When, on the morning of the first day, General Hatch's mounted infantry attacked the enemy on the extreme right with two of his batteries, the entire operation could be dimly seen in the mist from the hill where General Thomas stood, and by his side Major Powell watched the progress of the battle. When the Union troops fought their way to the top of the hill, and up to the enemy's works, for a few moments a cloud of mist obscured the scene; then the wind drove the clouds away, and with their glasses the two officers could see the stars and stripes waving over the enemy's fort, four or five miles in the distance. When the facts were fully demonstrated, General Thomas expressed unmeasured delight, and affirmed that he had no more fear of the result; the only thing then necessary was to press General Hood so that he could not escape. 
After the destruction of General Hood's army, Major Powell remained in Nashville some time until the sixteen batteries under his command were once more thoroughly equipped with horses and munitions.

Early in the spring of 1865 he asked for orders to report to the Commander of the Army of the Tennessee, General Howard, and receiving such orders, he was soon at his old post. In the meantime the Confederacy was gradually falling to pieces, and when Major Powell arrived at Louisville he was confident the end was near at hand. His term of enlistment had expired also, and general orders were issued permitting the troops to go home. With his wife he went to Detroit to visit his wife's family for a few weeks, and then to Wheaton, Illinois, the home of his father. 


\section{THE PROFESSOR.}

THE establishment of peace left the soldier without an occupa1 tion. He had willingly followed a life of toil and danger, when great national issues were at stake, but he could not be a soldier in time of peace. He therefore speedily sought some new occupation. After considering many different plans, he was prevailed upon to accept a nomination for the office of County Clerk of Du Page County, Illinois.

A few days later he received a letter from the President of the Illinois Wesleyan University, at Bloomington, offering him the professorship of geology in that institution. This he accepted at once, although the salary was but $\$ 1,000$ per annum, while the office of County Clerk was worth from $\$ 5,000$ to $\$ 6,000$. This university had previously given him the degree of $A$. B. and then of A. M., but the offer of the professorship was entirely unexpected. He left for Bloomington at once and entered upon his new duties.

The institution was more prosperous than had been supposed, and his salary, even for the first year, was better than had been promised. For three years he there led the quiet life of a professor of geology.

It was agreed when he accepted the position that a part of his time should be devoted to field geology and natural history, and that the greater part of his duties should be the organisation and building up of a museum.

During his life as a soldier, Major Powell did not forget the pursuits in which he had previously been so deeply interested, and often while in camp he applied himself to the study of natural history. During the more quiet pursuits of camp life, he found opportunities for studying the botany of the country in which he was sojourning. While in Kentucky and Tennessee, he made large collections of land and fresh-water shells. But the study in which he most interested himself was geology; and it was his custom to 
carry in his camp chest the geological reports of a district through which he travelled. There is now in the State Museum, at Normal, Illinois, a fine collection of fossils from Vicksburg and the region round about which he made while encamped in that region the winter after the fall of the city. In the same manner he made large collections of fossils in Tennessee, especially around Nashville, in the region made classic by Troost and Safford. Altogether, his notes on geology and natural history made during the war are quite voluminous.

On entering upon his duties at the Illinois Wesleyan University, his entire energies were directed to the development of methods of instruction in his favorite field of learning. It was his theory that the study of science should include much more than the textbook literature of the subject; that the student must be made familiar with the phenomena of nature; that the principles of any branch of natural science should be constructed by the pupil himself from observed facts; and that the function of the teacher should be chiefly that of guide. With this end in view, his time was largely devoted to the creation of a museum and the organisation of laboratories for instruction. In mineralogy his pupils were led to study the minerals themselves, and thus to become familiar with their characteristics; and many of them became skilful in blow-pipe analysis. His students in botany were at once introduced to the world of plants, and became collectors, and assisted him greatly in the gathering of plants for a fine herbarium. In zoölogy his pupils were taken to the woods and fields, and became collectors of mammals, birds, reptiles, fishes, and insects, and by the study of natural objects were trained in comparative anatomy.

He seems at this time to have found great difficulty in teaching geology, because it was almost impossible to introduce the students immediately into the presence of the facts, and he deeply lamented that they were so greatly dependent upon text-books. To correct this evil, even to a limited extent, he organised field excursions, and, as far as possible, adopted object-studies of rocks and fossils.

In this manner the days and years of professional life were passed, training students by research in field. and laboratory and by courses of lectures; and it may be well understood that his classes rapidly increased in size, and that he gathered about him a large number of young men who, inspired with his own enthusiasm, became earnest and successful scholars.

At the same time, the Professor took an earnest affirmative part in the public discussions of the importance of enlarging and 
perfecting the general college curriculum by the introduction of more science studies, - a question then fairly begun and not yet ended. In public lectures and addresses throughout the State, he did much toward creating a sentiment in favor of the opinions so earnestly embraced by himself.

During this time he was still secretary of the Illinois Natural History Society. This society was located in the hall of the Normal University at Normal, a suburb of Bloomington, and in that institution he delivered a course of lectures on geology. At the request of the officers of the institution, in the winter of $1866-1867$, he went to Springfield and secured from the legislature a small endowment for the museum of the Normal University. On his return he was elected to the curatorship, with the understanding that he should be called upon to deliver a course of lectures on geology during each winter.

During the next spring, Professor Powell organised an expedition, from the members of the graduating class in the Wesleyan University and students in the Normal University, for the purpose of crossing the Great Plains and visiting the mountain regions of Colorado to make collections and studies in natural history and geology. This excursion was one of the earliest of its kind in this country, and inaugurated a practice of the highest value to science, for it has now come to be recognised that field-study is a necessary part of a course of instruction in any branch of natural science.

Early in May the Professor organised his party, on the Missouri River near Council Bluffs. It was composed of sixteen students, his wife and himself, and was outfitted with two wagons and the necessary teams, and a number of riding animals. The equipment for natural history collection was very thorough, especially for the collection of vertebrate animals, insects, and plants, and to each member of the party was assigned a specified share in the work for which the expedition was organised.

The journey across the plains was slowly made, the party occupying itself from day to day in the collection of natural history materials found along the route. Some were chasing wild animals, some capturing butterflies in nets, some gathering plants to be pressed; and the Professor himself, while directing all of these operations, was also engaged in making geological examinations and collecting fossils. It was a busy merry party, and at night the camp was made hilarious with song and story.

At that time the Pacific railroads were not built, and in the wilderness of plains lurked Indian tribes, for which the party had 
to keep up a constant watch. As they moved by day, outriders guarded their little trail, and at night guards were established. Sometimes they camped on the same ground with other travellers pushing westward,- "pilgrims," as they were called in those times, - and common guards were established over large camps. For much of the distance they travelled in sight of the Platte River, a broad stream of shallow, muddy water, on the banks of which, at rare intervals, cottonwood groves were seen. At last, in crossing the Bijou Basin, about fifty miles from Denver, the party came in sight of the Rocky Mountains, and were filled with enthusiasm as the highland to which they were destined came into view. Ten days later the whole party were engaged in crossing the Rampart Range, as it is now called, sixty miles south of Denver, taking with them their wagons and animals, by a route explored by themselves. The college boys were teamsters, cooks, and laborers, as well as students, and with good cheer and great skill they climbed the mountain range, opening their way through forests with the axe, and sometimes finding it necessary to take wagons to pieces in order to get them up the rocks.

But days of great labor, endured with the utmost good-will, brought them into Bergen Park, on the western side of the divide. This is a long valley, with a mountain range on either side, enclosed at the north by a group of lofty crags known as Devil's Head, and at the south by Pikes Peak.

In Bergen Park they camped for nearly a month, and made a great variety of natural history collections. Thence the party moved to the foot of Pikes Peak, which they essayed to climb. At that time there was no Signal Service station at the summit, and no trail led up its steep sides as at present. The Professor explored a route up the north side. The ascent was one of much adventure, and required great labor; but at last, about three o'clock one afternoon, the whole party reached the summit. Nobody in the party had ever before been above the timber line, much less on a mountain's summit, among perpetual snows, and unfortunately, having had little experience, the descént was commenced too late in the afternoon; night came on with terrible cold, and in the darkness they had to make their way down rocks and over steep places, until they could reach the timber line. At last this was accomplished, and they went into camp for the remainder of the night, with no other shelter than rocks and logs, and preserved from perishing with cold by the huge fires which they built. The next day they returned to their camp at the foot of the moun- 
tain. Altogether, three days had been filled with the ascent and descent of Pikes Peak, probably by a route never before and never since taken.

From Pikes Peak the party went round to South Park, and although it was midsummer, two days of the trip were through a blinding snow. They camped in South Park for two or three weeks, and from the rendezvous which was established many of the mountains round about were climbed. One of the most noteworthy excursions was the ascent of Mount Lincoln, a peak I4,300 feet above the level of the sea.

From South Park they went to Denver, where the party was broken up, and a number of the young students returned to their homes in the East. But Professor Powell, with his wife and two or three young men and a couple of hardy mountaineers, went from Denver over into Middle Park, where another month was spent in exploring the mountains around that beautiful valley. One of the most interesting expeditions made from Middle Park was about the head of Grand Lake and up into the high sierras to the east, in the region of Longs Peak, and from thence around Mount Sumner, on the divide between Middle and North Parks. On this trip the Professor made some interesting collections of bear, elk, wolverine, and other animals. But finally the snows came on and they were driven out of the mountains. In going from Middle Park back to Denver, they had to cross the range once more, at Berthoud Pass, during the latter part of November, after the snows had accumulated several feet in depth.

On arriving at Denver the collections of the expedition were prepared for shipping to the East, embracing the skins and skeletons of many mammals, a collection of many hundreds of birds, many reptiles and fishes, many bottles and boxes of insects, and especially a large collection of plants. There was also a great store of fossils, minerals, and volcanic rocks; all of which were taken east to enrich the museums at Normal, Bloomington, and other institutions.

Professor Powell spent the winter of $1867-1868$ in the arrangement and study of his collections and in lecturing. In the spring a new expedition was organised, designed primarily for the museum at Normal, of which he was now in charge; but other institutions gave him assistance. A small grant was made by the Illinois State Agricultural College, and the Smithsonian Institution furnished him the apparatus and outfit necessary for natural history collection and instruments required for geographical reconnoissance. 
Through the influence of General Grant, Congress authorised the Commissary General of the Army to furnish his party with rations wherever they might call for them at military posts in the Far West.

With all of these additions to his equipment, the Professor again organised a party, of students and naturalists, for a natural history expedition into western Colorado, with the design of ultimately exploring the canyons of the Colorado. Early in the summer of 1868 he established a rendezvous camp in Middle Park, where he added a number of hardy mountaineers who were expert trappers and travellers. For more than three months our naturalists were pursuing their studies and engaged in making collections in various departments through the region round about. At one time, Professor Powell, with a part of his men, crossed the Colorado or Front Range and ascended Longs Peak, which was then climbed for the first time. During the whole period he was himself chiefly occupied with studies at high altitudes, and he traversed the entire Colorado Range from Longs Peak to the South Platte. While engaged in this part of the work they usually camped at the timber line, and the days were spent among the crags and peaks. In this manner the study of the general structure of the mountains was made. Thence he went to Mount Lincoln and studied the great mountain masses at the head of Blue River, and then passed southward to the Gore Mountains. In this region a longer delay was made and the whole system of mountains carefully explored.

The Gore Mountains are a group of wonderfully picturesque crags and peaks, and previous to this time had been entirely unexplored. The account of them published by the Professor greatly attracted the attention of travellers, and later his name was given to the highest peak of the group by the people of Colorado.

During the two summers of study the mountains standing about Middle Park, and the whole country within, had thus been carefully studied so that the general geology of the district was now well known by the Professor, and large collections of minerals, fossils, and rocks had been made. The naturalists of the party had also collected rich stores of plants and animals, and at the close of the season they found themselves well rewarded. The material thus gathered was sent to Denver and thence shipped east to the museum at Normal, from which it was to be distributed to the several institutions contributing to the expense of the expedition.

But Professor Powell did not return to the East himself. With a part of his scientific corps and a number of mountaineers he 
crossed the mountains to the westward of Middle Park and went down to the valley of the White River, where he established winter quarters. Here three small log houses were built on the margin of a great cottonwood grove not far from the banks of the river.

It had been previously arranged that early in the winter some members of the party should return east; so in December while the main party remained behind at winter quarters Powell went with these persons, and with three or four hunters, northwestward to where the Union Pacific railroad now crosses Green River. The whole journey was through - a region at that time unknown and without roads and trails. When within about fifty miles of Green River they encountered a severe snow-storm and went into camp at the foot of Aspen Mountain until the storm had subsided. This is a wild and desolate region and of great interest to scientific travellers, and the mountain was the center of a district of country which subsequently became the theater of an elaborate geologic study by the Professor, the results of which were published in his report on the Uinta Mountains. On the third day the storm subsided, and the party toiling through deep snows soon found its way to Green River Station.

Having parted with his friends who were coming east, Professor Powell loaded his pack animals with supplies to return to winter camp. His route back was down the valley of the Green to the Uinta Mountains, thence eastward to what has since been called Brown Park. From this beautiful valley in the heart of the mountains he explored the upper canyons of Green River and a large part of another canyon lying farther south, then passed eastward exploring the Yampa River where it canyons through the Uinta Mountains, and from the Yampa River southward to the winter camp on White River, arriving there on New Year's day. During the late winter months the canyons of White River were explored and excursions were made far up and down Green - River especially for the purpose of studying canyon geography. During the previous summer the Professor had explored the canyons of the Grand River where it passes through and out of Middle Park, having constructed small boats for this purpose. $\mathrm{He}$ had also made a careful study of some of the canyons of the Blue River. All of these examinations were made for the purpose of determining the best methods of exploring the canyons of the Colorado.

The winter spent on the White River was one of great interest to the Professor and his party, which again included Mrs. Powell. 
The entire winter was one of great activity in making explorations and collections. During the greater part of the time the Ute Indians were encamped in the same valley, and the Professor spent the long winter evenings in studying the Ute language and collecting the myths and noting the habits and customs of these interesting people. The presence of the Indians added greatly to the entertainment of the party, for all winter long they were engaged in festivities, and often at night were found performing their weird ceremonies of magic, - their "medicine rites." The hunters of the party abundantly supplied the camp with game; at one time they brought down twenty-three deer from a mountain about twenty miles from camp.

The valley, now known as Powell Valley, is a beautiful stretch of meadow glade, about ten miles long and from one to two miles broad, inclosed by mountains and steep cliffs on every side. Here the horses and mules, about twenty in number, roamed through the winter, but were brought up to the camp every night by a herdsman, and from their number the animals necessary for next day's ride were caught each night.

During this winter, as during the previous summer, extensive scientific collections were made.

Late in March winter camp was broken up, and through deep snow, with great toil, the party found their way over the mountains into Brown Park, in the heart of the Uinta Mountains. From Brown Park they went to Fort Bridger, where new operations were to be inaugurated, for the Professor had determined to explore the canyons of the Colorado. He at once shipped all his collections to the East, and leaving his party encamped on Green River, went to Chicago, for the purpose of constructing boats to be used in the exploration of the Green and Colorado Rivers. It had been his plan to construct boats in the field, and he had brought with him the necessary tools; but at that time a great rivalry had sprung up between the two great railroads, the Union Pacific, starting from Omaha and building westward, and the Central Pacific, starting in California and coming eastward. This rivalry resulted in the building of the transcontinental railroad with unexpected rapidity, and already the track had been laid as far westward as the Green River. The Professor determined to take advantage of this fact by having his boats built in Chicago, where the work could be more skilfully done, and shipping out by rail.

Having thus decided to enter upon extensive explorations, Powell's life as a college professor ended. 


\section{THE EXPLORER.}

DROFESSOR Powell saw in the parks and canyons of Colorado more than a mere training-school for students. Vast unexplored regions, hitherto represented on all maps by an utter blank, astonished and attracted him. He knew that through this unexplored territory must flow that great river, the Colorado of the West, unknown for much of its course to civilised man.

$\mathrm{He}$ had heard many wonderful stories from the Indians concerning the stupendous canyon. The Indians warned him not to enter this dreadful gorge; they considered it disobedience to the gods, and contempt for their authority, and declared that it would surely bring wrath and ruin on any who attempted it. The mysteries of the canyon were woven into the strange myths of their religion.

After finding that he understood their language and was a good friend to them, they persisted in their warning, and with much solemnity told him the following legend of a Numa chief :

"Long ago there was a great and wise chief who mourned the death of his wife, and would not be comforted until Ta-vwoats, one of the Indian gods, came to him and told him she was in a happier land, and offered to take him there that he might see for himself, if upon his return he would cease to mourn. The great chief promised. Then Ta-vwoats made a trail through the mountains that intervene between that beautiful land, the balmy region in the great West, and this the desert home of the poor Numa. The trail was the gorge of the Colorado. Through it he led him, and when they returned the deity exacted from the chief a promise that he would tell no one of the joys of that land, lest through discontent with the circumstances of this world, they should desire to go to heaven. Then he rolled a river into the gorge, a mad raging stream that should engulf any who might attempt to enter thereby."

Despite all the warnings of the red men, on the 24th of May, 
I869, the party of explorers launched their boats in the Green River, one of the largest tributaries of the Colorado. The boats were four in number; three were built of oak, staunch and firm, double-ribbed, with double stem- and stern-posts, and further strengthened by bulk-heads, dividing each into three compartments. Two of these were decked fore and aft, forming water-tight cabins which it was expected would buoy the boats should the waves roll over them in rough water. The little vessels were twenty-one feet long, and without cargo each could be carried by four men. The fourth boat was made of pine, very light, sixteen feet in length, with a sharp cut-water; this was built for fast rowing, and was divided into compartments like the others. They were fitted out with rations for ten months, all kinds of implements needed on a voyage, plenty of ammunition, and many scientific instruments.

Of that memorable expedition of four months in the canyons of the Colorado I can only give a glimpse.

The hero was never daunted. He had a fixed purpose, and was willing, if need be, to face death to accomplish something for science. Let us follow him and hear in his own words how the expedition was manned.

" J. C. Sumner and William H. Dunn are my boatmen in the 'Emma Dean'; then follows 'Kitty Clyde's Sister,' manned by W. H. Powell and G. T. Bradley; next the 'No Name,' with O. G. Howland, Seneca Howland, and Frank Goodman; and last comes the 'Maid of the Canyon' with W. R. Hawkins and Andrew Hall." 1

The general course of the river is southward, and to the south is a great upland, the Uinta Mountains, lying athwart its course. Through this upland the river burrows in a series of deep canyons; and in these canyons the excitement and danger of the voyage begin.

"May 30.-This morning we are ready to enter the mysterious canyon, and start with some anxiety. The old mountaineers tell us that it cannot be run; the Indians say, 'Water heap catch 'em,' but all are eager for the trial, and off we go.

"Entering Flaming Gorge, we quickly run through it on a swift current and emerge into a little park. Half a mile below, the river wheels sharply to the left, and we turned into another canyon cut into the mountain. We enter the narrow passage. On either side

1 The full narrative of the voyage through the Colorado Canyons, from which these passages are extracted, is contained in Exploration of the Colorado River of the West, by J. W. Powell, Washington, 1875. A popular account of the voyage, likewise by Powell, appeared in Scribner's Monthly for January, February and March 1875 


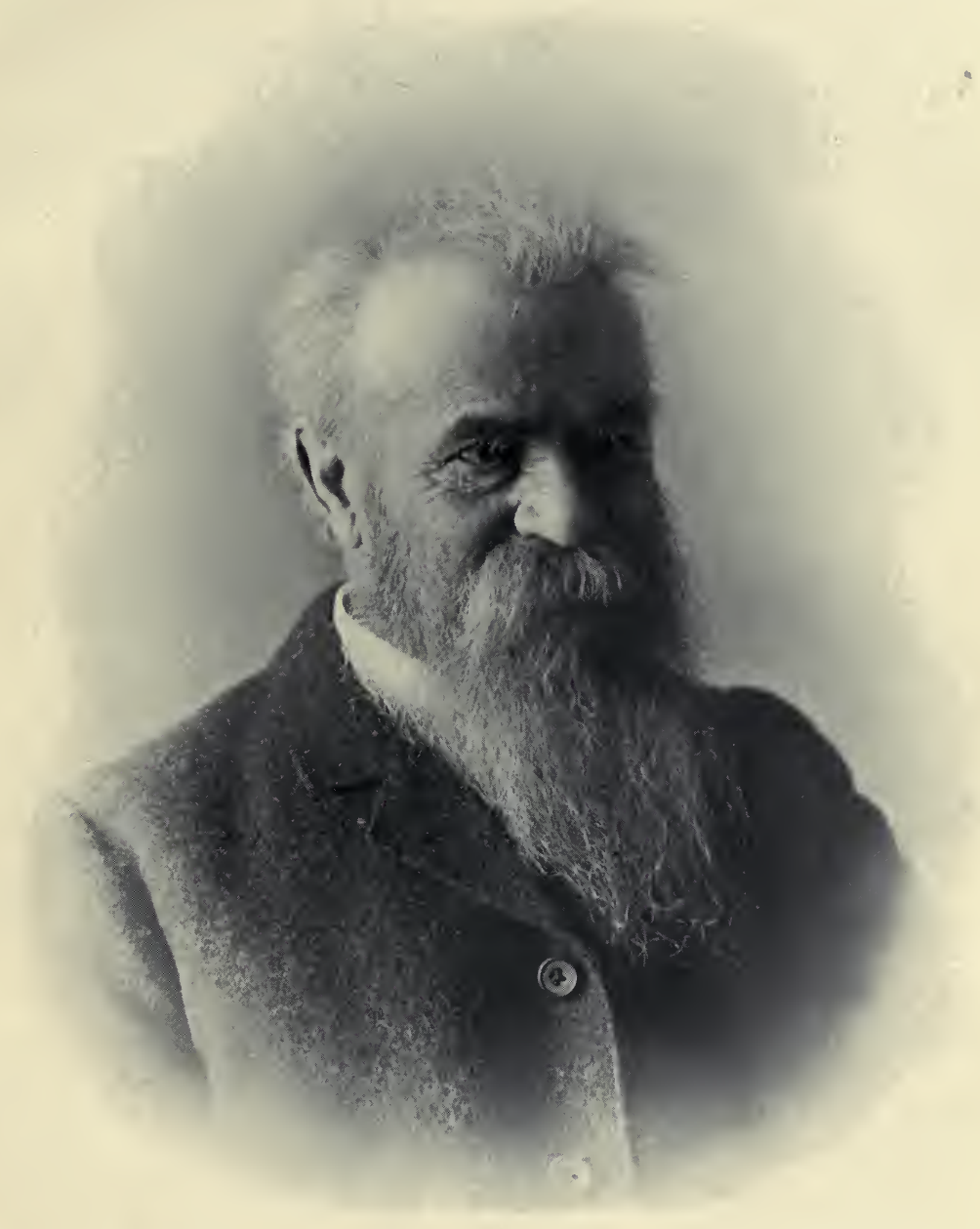

The Late Major Powell. ${ }^{1}$

1 A recent portrait taken by Mr. De Lancey Gill, the Art Photographer of the Smithsonian Institution. 

the walls rapidly increase in altitude. On the left are overhanging ledges and cliffs five hundred-a thousand-fifteen hundred feet high.

"On the right, the rocks are broken and ragged, and the water fills the channel from cliff to cliff. Now the river turns abruptly around a point to the right, and the waters plunge swiftly down among great rocks; and here we have our first experience with canyon rapids. I stand up on the deck of my boat to seek a way among the wave-beaten rocks. All untried as we are with such waters, the moments are filled with intense anxiety. Soon our boats reach the swift current; a stroke or two, now on this side, now on that, and we thread the narrow passage with exhilarating velocity, mounting the high waves, whose foaming crests dash over us, and plunging into the troughs, until we reach the quiet water below; and then comes a feeling of great relief. Our first rapid is run. Another mile, and we come into the valley again.

"Let me explain this canyon. Where the river turns to the left above, it takes a course directly into the mountain, penetrating to its very heart, then wheels back upon itself, and runs out into the valley from which it started only half a mile below the point at which it entered; so the canyon is in the form of an elongated letter $U$, with the apex in the center of the mountain. We name it Horseshoe Canyon."

For a week their course winds among foothills, with minor gorges and minor rapids, which prepare and train them for the grandeur and the danger that await them. At last they enter the heart of the mountain through the "Gate of Lodore."

"June 8.-We enter the canyon, and, until noon, find a succession of rapids, over which our boats have to be taken.

"Here I must explain our method of proceeding at such places. The 'Emma Dean' goes in advance; the other boats follow, in obedience to signals. When we approach a rapid, or what on other rivers would often be called a fall, I stand on deck to examine it, while the oarsmen back water, and we drift on as slowly as possible. If I can see a clear chute between the rocks, away we go; but if the channel is beset entirely across, we signal the other boats, pull to land, and I walk along the shore for closer examination. If this reveals no clear channel, hard work begins. We drop the boats to the very head of the dangerous place, and let them over by lines, or make a portage, frequently carrying both boats and cargoes over the rocks, or, perhaps, only the cargoes, if it is safe to let the boats down. 
"The waves caused by such falls in a river differ much from the waves of the sea. The water of an ocean wave merely rises and falls; the form only passes on, and form chases form unceasingly. A body floating on such waves merely rises and sinks-does not progress unless impelled by wind or some other power. But here, the water of the wave passes on, while the form remains. The waters plunge down ten or twenty feet, to the foot of a fall; spring up again in a great wave; then down and up, in a series of billows, that gradually disappear in the more quiet waters below; but these waves are always there, and you can stand above and count them.

"A boat riding such, leaps and plunges along with great velocity. Now, the difficulty in riding over these falls, when the rocks are out of the way, is in the first wave at the foot. This will sometimes gather for a moment, heaping up higher and higher, until it breaks back. If the boat strikes it the instant after it breaks, she cuts through, and the mad breaker dashes its spray over the boat, and would wash us overboard did we not cling tight. If the boat, in going over the falls, chances to get caught in some side current, and is turned from its çourse, so as to strike the wave 'broadside on,' and the wave breaks at the same instant, the boat is capsised. Still, we must cling to her, for, the water-tight compartments acting as buoys, she cannot sink; and so we go, dragged through the waves, until still waters are reached. We then right the boat, and climb aboard. We have several such experiences to-day.

"At night, we camp on the right bank, on a little shelving rock, between the river and the foot of the cliff; and with night comes gloom into these great depths.

"After supper, we sit by our camp fire, made of driftwood caught by the rocks, and tell stories of wild life; for the men have seen such in the mountains, or on the plains, and on the battlefields of the South. It is late before we spread our blankets on the beach."

In another rapid the 'No Name' is wrecked, much of her cargo is lost, and her crew for a time are in great peril.

"During the afternoon [Jure 15 ] we run down, three-quarters of a mile, on quiet water, and land at the head of another fall. On examination, we find that there is an abrupt plunge of a few feet, and then the river tumbles, for half a mile, with a descent of a hundred feet, in a channel beset with great numbers of huge boulders. This stretch of the river is named Hell's Half-Mile. 
"The remaining portion of the day is occupied in making a trail among the rocks to the foot of the rapid.

"June 16.-Our first work this morning is to carry our cargoes to the foot of the falls. Then we commence letting down the boats. We take two of them down in safety, but not without great difficulty; for, where such a vast body of water, rolling down an inclined plane, is broken into eddies and cross currents by rocks projecting from the cliffs and piles of boulders in the channel, it requires excessive labor and much care to prevent their being dashed against the rocks or breaking away. Sometimes we are compelled to hold the boat against a rock, above a chute, until a second line, attached to the stem, is carried to some point below, and, when all is ready, the first line is detached, and the boat given to the current, when she shoots down, and the men below swing her into some eddy.

"At such a place, we are letting down the last boat, and, as she is set free, a wave turns her broadside down the stream, with the stem, to which the line is attached, from shore and a little up. They haul on the line to bring the boat in, but the power of the current, striking obliquely against her, shoots her out into the middle of the river. The men have their hands burned with the friction of the passing line; the boat breaks away, and speeds, with great velocity, down the stream.

"The 'Maid of the Canyon' is lost, so it seems; but she drifts some distance and swings into an eddy, in which she spins about, until we arrive with the small boat and rescue her."

Ten days of hard work bring them to the south base of the Uinta Mountains, but they are still among canyons, and the river is still swift and difficult. They are in the Plateau Province, where the uplands are tables, flat or sloping, bounded by cliffs, and adorned by buttresses and pinnacles. Among these the Green River is joined by the Grand, to make the Colorado. The whole narrative is a tale of adventure; each successive canyon gives a new type of scenery; each climbing of a canyon wall reveals a new wonderland; each roaring rapid yields a new problem in navigation. At last, near the middle of August, the Grand Canyon is reached, and all phases of the journey-the labor and peril, the beauty and grandeur, and the scientific interest-find their superlative expression.

"About eleven o'clock [August I4] we hear a great roar ahead, and approach it very cautiously. The sound grows louder and louder as we run, and at last we find ourselves above a long, broken 
fall, with ledges and pinnacles of rock obstructing the river. There is a descent of, perhaps, seventy-five or eighty feet in a third of a mile, and the rushing waters break into great waves on the rocks, and lash themselves into a mad, white foam. We can land just above, but there is no foot-hold on either side by which we can make a portage. It is nearly a thousand feet to the top of the granite, so it will be impossible to carry our boats around, though we can climb to the summit up a side gulch, and, passing along a mile or two, can descend to the river. This we find on examination; but such a portage would be impracticable for us, and we must run the rapid, or abandon the river. There is no hesitation. We step into our boats, push off and away we go, first on smooth but swift water, then we strike a glassy wave, and ride to its top, down again into the trough, up again on a higher wave, and down and up on waves higher and still higher, until we strike one just as it curls back, and a breaker rolls over our little boat. Still, on we speed, shooting past projecting rocks, till the little boat is caught in a whirlpool, and spun around several times. At last we pull out again into the stream, and now the other boats have passed us. The open compartment of the 'Emma Dean' is filled with water, and every breaker rolls over us. Hurled back from a rock, now on this side, now on that, we are carried into an eddy, in which we struggle for a few minutes, and are then out again, the breakers still rolling over us. Our boat is unmanageable, but she cannot sink, and we drift down another hundred yards, through breakers; how, we scarcely know. We find the other boats have turned into an eddy at the foot of the fall, and are waiting to catch us as we come, for the men have seen that our boat is swamped. They push out as we come near, and pull us in against the wall. We bail our boat, and on we go again.

"The walls, now, are more than a mile in height-a vertical distance difficult to appreciate. Stand on the south steps of the Treasury building, in Washington, and look down Pennsylvania Avenue to the Capitol Park, and measure this distance overhead, and imagine cliffs to extend to that altitude, and you will understand what I mean; or, stand at Canal street, in New York, and look up Broadway to Grace Church, and you have about the distance; or, stand at Lake street bridge, in Chicago, and look down to the Central Depot, and you have it again.

"A thousand feet of this is up through granite crags, then steep slopes and perpendicular cliffs rise, one above another, to the summit. The gorge is black and narrow below, red and gray and 
flaring above, with crags and angular projections on the walls, which, cut in many places by side canyons, seem to be a vast wilderness of rocks. Down in these grand, gloomy depths we glide, ever listening, for the mad waters keep up their roar; ever watching, ever peering ahead, for the narrow canyon is winding, and the river is closed in so that we can see but a few hundred yards, and what there may be below we know not; but we listen for falls, and watch for rocks, or stop now and then, in the bay of a recess, to admire the gigantic scenery. And ever, as we go, there is some new pinnacle or tower, some crag or peak, some distant view of the upper plateau, some strange shaped rock, or some deep, narrow side canyon."

After some days a rapid is reached of such formidable character that nearly a day is spent in climbing the walls to study it.

"I decide that it is possible to let down over the first fall, then run near the right cliff to a point just above the second, where we can pull out into a little chute, and, having run over that in safety, we must pull with all our power across the stream, to avoid the great rock below. On my return to the boat, I announce to the men that we are to run it in the morning.

"After supper Captain Howland asks to have a talk with me. We walk up the little creek a short distance, and I soon find that his object is to remonstrate against my determination to proceed. He thinks that we had better abandon the river here. Talking with him, I learn that his brother, William Dunn, and himself have determined to go no farther in the boats. So we return to camp. Nothing is said to the other men.

"For the last two days, our course has not been plotted. I sit down and do this now, for the purpose of finding where we are by dead reckoning. It is a clear night, and I take out the sextant to make observation for latitude, and find that the astronomic determination agrees very nearly with that of the plot-quite as closely as might be expected, from a meridian observation on a planet. In a direct line, we must be about forty-five miles from the mouth of the Rio Virgen. If we can reach that point, we know that there are settlements up that river about twenty miles. This forty-five miles, in a direct line, will probably be eighty or ninety in the meandering line of the river. But then we know that there is comparatively open country for many miles above the mouth of the Virgen, which is our point of destination.

"As soon as I determine all this, I spread my plot on the sand, and wake Howland, who is sleeping down by the river, and show 
him where I suppose we are, and where several Mormon settlements are situated.

"We have another short talk about the morrow, and he lies down again; but for me there is no sleep. All night long, I pace up and down a little path, on a few yards of sand beach, along by the river. Is it wise to go on? I go to the boats again, to look at our rations. I feel satisfied that we can get over the danger immediately before us; what there may be below I know not. From our outlook yesterday, on the cliffs, the canyon seemed to make another great bend to the south, and this, from our experience heretofore, means more and higher granite walls. I am not sure that we can climb out of the canyon here, and, when at the top of the wall, I know enough of the country to be certain that it is a desert of rock and sand, between this and the nearest Mormon town, which, on the most direct line, must be seventy-five miles away. True, the late rains have been favorable to us, should we go out, for the probabilities are that we shall find water still standing in holes, and, at one time, I almost conclude to leave the river. But for years I have been contemplating this trip. To leave the exploration unfinished, to say that there is a part of the canyon which I cannot explore, having already almost accomplished it, is more than I am willing to acknowledge, and I determine to go on.

"I wake my brother, and tell him of Howland's determination, and he promises to stay with me; then I call up Hawkins, the cook, and he makes a like promise; then Sumner, and Bradley, and Hall, and they all agree to go on.

"August 28. - At last daylight comes, and we have breakfast, without a word being said about the future. The meal is as solemn as a funeral. After breakfast, I ask the three men if they still think it best to leave us. The elder Howland thinks it is, and Dunn agrees with him. The younger Howland tries to persuade them to go with the party, failing in which, he decides to go with his brother."

So the party is divided. Powell leaves a boat behind, for use of the three men if they fail to scale the cliff, and then successfully runs the rapid. Fortunately no other serious difficulty is encountered, and in the forenoon of the following day the two boats glide at last from between the gloomy walls into the broad daylight of an open valley. The weary river, as though sharing the joy and relief of the explorers, spreads out its unhampered waters, to bask and loiter in the sun.

The adventurous voyage is ended. 
The three men who climbed the canyon wall and thus escaped the dangers of the river, ran unwittingly into still greater peril and never reached the settlements. Their story was not fully known until the autumn of the following year, when Professor Powell encamped with a band of Plateau Indians, the Kai'-vav-its, was visited by Indians of another band, the Shi'-vwitz.

"This evening, the Shi'-vwitz, for whom we have sent, come in, and, after supper, we hold a long council. A blazing fire is built, and around this we sit-the Indians living here, the Shi'vwits, Jacob Hamblin, and myself. Hamblin speaks their language well, and has a great influence over all the Indians in the region round about. He is a silent, reserved man, and when he speaks it is in a low, quiet way that inspires great awe. His talk is so low that they must listen attentively to hear, and they sit around him in deathlike silence. When he finishes a measured sentence, the chief repeats it, and they all give a solemn grunt. But, first, I fill my pipe, light it, and take a few whiffs, then pass it to Hamblin; he smokes, and gives it to the man next; and so it goes around. When it has passed the chief, he takes out his own pipe, fills, and lights it, and passes it around after mine. I can smoke my own pipe in turn, but when the Indian pipe comes around I am nonplussed. It has a large stem, which has, at some time, been broken, and now there is a buckskin rag wound around it, and tied with sinew, so that the end of the stem is a huge mouthful, and looks like the burying ground of old dead spittle, venerable for a century. To gain time, I refill it, then engage in very earnest conversation, and, all unawares, I pass it to my neighbor unlighted.

"I tell the Indians that I wish to spend some months in their country during the coming year, and that I would like them to treat me as a friend. I do not wish to trade; do not want their lands. Heretofore I have found it very difficult to make the natives understand my object, but the gravity of the Mormon missionary helps me much. I tell them that all the great and good white men are anxious to know very many things; that they spend much time in learning, and that the greatest man is he who knows the most. They want to know all about the mountains and the valleys, the rivers and the canyons, the beasts, and birds, and snakes. Then I tell them of many Indian tribes, and where they live; of the European nations; of the Chinese, of Africans, and all the strange things about them that come to my mind. I tell them of the ocean, of great rivers and high mountains, of strange beasts and birds. At last I tell them I wish to learn about their canyons and moun- 
tains, and about themselves, to tell other men at home; and that I want to take pictures of everything, and show them to my friends. All this occupied much time, and the matter and manner made a deep impression.

"Then their chief replies: "Your talk is good, and we believe what you say. We believe in Jacob, and look upon you as a father. When you are hungry, you may have our game. You may gather our sweet fruits. We will give you food when you come to our land. We will show you the springs, and you may drink; the water is good. We will be friends, and when you come we will be glad. We will tell the Indians who live on the other side of the great river that we have seen you, and you are the Indians' friend. We will tell them you are Jacob's friend. We are very poor. Look at our women and children; they are naked. We have no horses; we climb the rocks, and our feet are sore. We live among rocks, and they yield little food and many thorns. When the cold moons come, our children are hungry. We have not much to give; you must not think us mean. You are wise; we have heard you tell strange things. We are ignorant. Last year we killed three white men. Bad men said they were our enemies. They told great lies. We thought them true. We were mad; it made us big fools. We are very sorry. Do not think of them, it is done; let us be friends. We are ignorant-like little children in understanding compared with you. When we do wrong, do not get mad, and be like children too.

" When white men kill our people, we kill them. Then they kill more of us. It is not good. We hear that the white men are a great number. When they stop killing us, there will be no Indian left to bury the dead. We love our country; we know not other lands. We hear that other lands are better; we do not know. The pines sing, and we are glad. Our children play in the warm sand; we hear them sing, and are glad. The seeds ripen, and we have to eat, and we are glad. We do not want their good lands; we want our rocks, and the great mountains where our fathers lived. We are very poor; we are very ignorant; but we are very honest. You have horses and many things. You are very wise; you have a good heart. We will be friends. Nothing more have I to say.'

"Mr. Hamblin fell into conversation with one of them, and held him until the others had left, and then learned more of the particulars of the death of the three men. They came upon the Indian village almost starved and exhausted with fatigue. They 
were supplied with food, and put on their way to the settlements. Shortly after they had left, an Indian from the east side of the Colorado arrived at their village, and told them about a number of miners having killed a squaw in a drunken brawl, and no doubt these were the men. No person had ever come down the canyon; that was impossible; they were trying to hide their guilt. In this way he worked them into a great rage. They followed, surrounded the men in ambush, and filled them full of arrows." 


\section{THE INVESTIGATOR.}

THE last chapter leaves Major Powell at the mouth of the Rio 1 Virgen in the autumn of 1869 . The remainder of his life is to be reckoned in results, and the order of events is less important, but it is fitting to complement the preceding narrative in a few paragraphs before attempting to outline his scientific researches.

Although the adventurous voyage of the Colorado solved a geographic problem and added a volume of knowledge to the common stock, its results were far from exhaustive, for among its discoveries were a host of new and attractive problems to be attacked. Each river that came to the Colorado issued from a canyon of its own and invited exploration. Each climbing of a canyon wall gave a glimpse of a sculptured and tinted plateau land such as traveller had never described.

In no other part of the earth had there been revealed to the geologist a great desert so bare of vegetation and soil as to expose the naked rock, and at the same time so dissected by a ramifying system of trenches as to reveal its deep-lying anatomy. The idea of expanding the line of exploration into a belt of exploration was immediately conceived and this soon grew into a plan for the survey of the broad area of the Colorado Plateaus. It was first determined to repeat the voyage of the river in a more deliberate way, bringing supplies by land to various points demonstrated by the exploration to be accessible from the shore, making many excursions from the river, and complementing the river work by independent exploration on land. Up to this point Powell had depended on personal resources and those of private institutions, but his plans now outgrew these slender means and he appealed to the General Government for aid. He was granted a first appropriation of twelve thousand dollars.

The line of the river was retraversed by boat in 1871 and 1872 ; and a survey of adjacent country was carried forward, with grad- 
ually expanding scope and organisation, until the reconstitution of western surveys in 1879 .

Powell's personal work was in geology and ethnology. In 1873 he accepted a temporary commission from the Indian Bureau, because his duties as commissioner would require him to visit, many tribes in Utah, Nevada, California, and Idaho, and thus enable him to extend his acquaintance with Indian languages, mythologies, and social institutions. In 1874 and 1875 he made a special study of the eastern Uinta Mountains and adjacent portions of the Green River basin. In later years the field work of the Survey was largely delegated to his colleagues, and his own attention was given to the publication of results and to new undertakings.

The most important new undertaking referred to the public lands. His many journeys in the states and territories of the Great Plains and beyond, gave him exceptional opportunity to observe the manner of development of the new country, and he was profoundly impressed with the vicious results of ill-adjusted land laws. Our laws, framed for the well-watered East, are not adapted to the needs of the arid West. In a dry country the soil yields crops only when artificially watered, and the ownership of the scant water of the streams should go with the ownership of the best farming land to which it can be conveyed by canals; but the common law gives the use of the stream to the adjacent land, whether it is suitable for farming or not. The arid land that cannot be watered is useful chiefly for grazing, but its herbage is so scant that a single stock raiser requires a large tract-much larger than our laws allow an individual to homestead or purchase. So there is no private title to the grazing lands, and there is no incentive to the improvement of their natural resources. The laws under which title is given to mineral lands assume that ores lie in regular sheets, dipping down into the earth, and as few ores are so disposed titles are uncertain and the mining industry is burdened with excessive litigation. Powell's attempt to procure the enactment of better laws has proved, up to the present time, the least successful of all his undertakings, but it is still possible that through the slow action of public opinion his endeavors may bear fruit.

In 1877 his corps prepared an economic map of Utah, showing the distribution of irrigable timber and grazing lands, and this was published in conjunction with a volume by Powell in which he discussed the Western land problem so far as irrigation and pasturage are concerned. The book is entitled The Lands of the Arid 
Region. Subsequently Congress authorised the appointment of a "Public Lands Commission" to investigate the whole subject of the land laws, and Powell, being made a member of it, devoted much time in 1879 and 1880 to its work. Its report, in four thick volumes, is a monument to its industry, but the reforms it advocated have only in small part been made.

The survey developed as a sequel to the exploration of the Colorado canyons came eventually to be called the Survey of the Rocky Mountain Region. From similar small beginnings Dr. F. V. Hayden, likewise an explorer and geologist, developed the Survey of the Territories, and Captain George M. Wheeler, an engineer officer of the regular army, developed the Survey West of the rooth Meridian. All these were sustained by Congressional appropriations, their lines of investigation were largely the same, and they were rivals. The evils resulting from rivalry were many and were fully recognised, but for many years no reduction was made in the number of organisations because Congress could not agree which one to select for preservation. It was finally proposed to abolish all three and create instead a Geological Survey whose chief should be appointed by the President of the United States, and of this proposition Powell was the most active advocate. It was adopted by Congress in March, I879, and the direction of the new-born United States Geological Survey was given to Mr. Clarence King, a geologist who had already won distinction as chief of the Fortieth Parallel Survey.

Zoölogic and ethnologic researches, which had been conducted by the Surveys just abolished, were not included among the functions of the new organisation, but Congress made a special provision for ethnologic work by establishing a Bureau of Ethnology. Major Powell was made the Director of this Bureau and he was thus enabled to continue one of the most important lines of investigation of the survey he had been willing to have abolished.

The direction of the Geological Survey was held by Mr. King less than two years; he resigned in March, 1881. President Garfield immediately named Major Powell as his successor, sending the nomination to the Senate. It is the custom of that body to refer each nomination to an appropriate committee and take action only after the committee has made its report; but when the nominee is a senator his confirmation is considered immediately without asking the advice of a committee. It is one of the open secrets of the executive session of the Senate that Major Powell's nomina- 
tion was paid the exceptional compliment of immediate consideration and confirmation.

He directed the work of both bureaus until i 894. During this period the appropriations for the work of the Geological Survey were greatly increased, and its functions were from time to time enlarged, especially by the addition of investigations and surveys connected with the utilisation of the waters of the arid region for irrigation. In 1888 the Survey was instructed to classify the lands of the public domain, and especially to set apart as agricultural those which might be redeemed by irrigation. The provisions of the law were such that the Secretary of the Interior felt compelled to withdraw all public lands from sale pending their classification by the Geological Survey. This withdrawal aroused a storm of indignation, leading to the repeal of the new law and the reduction also of the appropriations for other work of the Survey. The disaster indicated diminished confidence on the part of Congress in the Director of the Survey, and led him to resign his office as soon as he could be sure of the appointment of a properly qualified successor. He retired gladly, as impaired health had for several years made heavy executive responsibilities an onerous burden, and he afterward watched with great pleasure the successful administration of his successor, Mr. Walcott.

Immediately after his resignation he submitted to a third operation on his wounded arm, which had given him much trouble, and thereafter sedulously husbanded his physical resources, devoting the remainder of his life to the elaboration and publication of a system of philosophy to which he had already given much thought. He retained the directorship of the Bureau of Ethnology, but delegated the chief labor of administration to another. This work was carried on despite a complication of bodily ailments, and his health steadily declined until his death, which occurred on the 23d of September, 1902 .

The study of nature falls logically into three categories: observation, classification, and explanation. One great part consists in the observation and description of phenomena, another in their classification and generalisation, the putting of like phenomena together and the substitution of summary statements for the enumeration of details. A third part furnishes the explanation of groups of phenomena, or constructs theories. The three interlock and interact. Most good observation is guided by antecedent classification or theory; the observer either gathers facts within a specific category, or he seeks crucial facts to test an hypothesis. Before 
the discovery of satisfactory theories, classifications are artificial and tentative.

These interdependencies and others that might be named render it impossible always to discriminate the three kinds of scientific work, and it is still less possible to classify scientific workers under three corresponding heads; but it is nevertheless true that a large body of workers devote their lives to observation on selected subjects and generalise but little; and that others deal chiefly with generalisation and theory. The best observers are acquainted with competing hypotheses as to the phenomena under observation; and the observations of those ignorant of hypotheses are comparatively worthless. The best theorists are personally familiar with observation; and the theories of those who are not also observers are unsuccessful.

It results that the great investigators, those who contribute classifications and theories which are at once comprehensive and stable, are not merely men with great power of generalisation and analysis, they are also men whose training as observers enables them to sort the good from the bad in the recorded observations of others. The greatest investigators have begun with mere observation, or with the collection of specimens, have then discussed their own observations, and finally in full maturity have reared noble structures of philosophy on foundations far broader than the observation of an individual could compass.

Powell's early scientific work made no important literary record. He collected the mammals, reptiles, shells, plants, fossils, and minerals of his region, ascertained their names, and prepared faunal and floral lists, but in this he did little more than follow the tracks of others. Whether consciously or unconsciously, he was training his mind to habits of close observation and establishing an all-important respect for the facts of nature. His contributions to the world's knowledge and the world's philosophy began in later life and pertain to other fields of research. As an explorer he contributed to geography, geology, and ethnology; ethnologic study led him to the broader science of anthropology; and the evening of his life was given to the broadest of all generalisations and the most comprehensive of all theories, - a system of philosophy.

His contributions to physical geography and geology are chiefly contained in three treatises. In his volume on the Exploration of the Colorado River the first part is a narrative of the voyage-the narrative quoted in the preceding chapter, -and the second part is a systematic account of the physical features of the river val- 
ley. The second treatise makes a volume by itself, and has for its theme the Geology of the Eastern Portion of the Uinta Mountains. In these works the details of observation are not recited. The features of the country and the geologic structure are set forth in comprehensive statements, and are treated as texts for the discussion of the departments of geologic, philosophy to which their explanation belongs. The principal generalisations are: (I) a definition of the "plateau province," (2) a classification of mountain types, (3) a classification of valleys, and (4) a classification of the forms of displacement of the plateau province, with a demonstration of the equivalence of the fault and the monoclinal flexure. The chief additions to geologic theory appear in discussions of the physics of erosion and of the production of topographic forms by the joint action of upheaval and erosion. The term "base-level of erosion," first used in these discussions and now current wherever the forms of the land are studied, carries with it an idea of apparent simplicity but of far-reaching importance. A stream cannot wear down below its base-level, and the rate and manner of degradation of a region depend on the relation of the region to the baselevels of its streams.

It was shown that the degradation of mountains is many times more rapid than that of lowlands, and that mountains are therefore temporary elevations unless continuously renewed by uplift. All great mountains are young.

When the strata deposited by the sea are lifted into land, rivers begin to flow over them. The initial direction of the rivers is down the slope, and this is also the direction of the dip. It is found, however, that many drainage systems are quite independent of the direction of the dip, and, still more strange, that rivers often cut their way through mountain ranges instead of going around them. A generation of geologists observed this and wondered at it without finding an adequate explanation, but the present generation has discovered three different ways in which "inconsequent" drainage may arise and has arisen. Two of these ways were discovered by Powell, and to characterise them he introduced the terms "superimposed drainage" and "antecedent drainage."

When a region of disturbed strata has in long ages been degraded nearly to base-level, then sinks below water level and receives a coating of sediments, and then is lifted into land, its new drainage conforms to the overlying strata. With continued uplift and continued degradation the newer deposits are destroyed and the drainage system sinks into the underlying disturbed strata. 
The drainage is independent of the system of dips into which it is lowered and on which it is "superimposed."

If a mountain range is slowly uplifted athwart the course of a large river, the river wears its channel deeper and maintains its course. When the uplift is completed, the mountain stands in two parts, divided by the river. The direction of the stream's flow is independent of the dips of the rocks in the mountain, because the drainage is "antecedent" to the uplift.

His third important treatise on physical geography constitutes the first three chapters of a monograph by the National Geographic Society on the physiography of the United States. It sets forth the broader processes by which the surface of the earth is modified, characterises the features to which these processes give rise, and classifies the land of the United States into physiographic regions or provinces.

Anthropology is Powell's favorite science, and to it his greatest contributions have been made. Nor need his preference occasion surprise. Geology is young, and being young has had the advantage of modern inductive methods from its birth. Its growth has been so rapid that its great generalisations have been attained, and present progress is by slow stages, adding here a little and there a little. Great indeed must be the future geologist who can earn the reputation of Lyell. But the study of man was begun in the far distant past, and it accumulated by early methods so large a body of theory that when better methods became known it was at first unable to accept and use them. It has resulted that inductive anthropology is a less developed science than geology. Moreover, anthropology is the great science of the future, for its results are to guide the development of human institutions. It has barely discovered its high destiny, and is beginning to train its powers for serious work.

The days that Powell has spent in intercourse with Indians for the purpose of studying their languages, their modes of thought, their institutions, their arts and their philosophies, aggregate several years of time. On the material thus gathered many printed volumes of description might be based. But the time necessary to. arrange and edit this material was never given because his erergies were consumed by more important work. A small portion only was published. A sketch of the Ancient Province of Tusayan appeared in Scribner's Monthly in I875; an address read at the Boston meeting of the American Association for the Advancement of Science was devoted to the Political System of the Wyandots; a 
few myths of the Utes were recited in the first annual report of the Bureau of Ethnology; and the material has been frequently drawn on for purposes of illustration; but as a body the observations are recorded only in note-books. And yet the time devoted to them was neither lost nor misspent, for it gave him the foundation of personal observation necessary to sound generalisation. It rendered him a rare critic of ethnologic material, - able by what seemed an intuition to select the grain for use and reject the chaff. More than this, it gave him the breadth of view for which he was distinguished. The American differ so widely-in many respects so radically-from the Aryan races that their comparative study yielded him generalisations he could never have derived from a comparison of Aryan peoples with one another. With the aid of books he brought yet other ethnic stocks within his view, testing and extending his generalisations and developing a system of anthropologic philosophy.

The framework of this system of philosophy was mentally arranged before any of it was given to the world, but the different parts have been elaborated and published in a somewhat fragmentary way and without strict adherence to their logical order. A few have appeared in the annual reports of the Bureau of Ethnology; the greater number have been prepared and read as addresses to various scientific societies and printed with their proceedings. They are thus widely scattered, and their plan and order, though ever in the mind of their author, and frequently communicated in conversation, have never appeared in print. The central essay is entitled Human Evolution, and was read to the Anthropological Society of Washington in 1883 . It begins by characterising the geologic, archæologic, historic, and ethnologic data through which the history of man's evolution is discovered. It then treats of the general character of that evolution. Human activities are then divided into five categories, and a brief sketch is given of the line of evolution within each category. The categories are : first, esthetic arts ; second, industrial arts ; third, institutions; fourth, languages ; fifth, philosophy. Of the remaining essays of the series, two logically precede this, in that they treat of the relation of human evolution to other evolution and the relation of the science of man to other sciences; eight logically follow it and develop the philosophy in detail.

An address to the Philosophical Society of Washington, likewise in $188_{3}$, is entitled Three Methods of Evolution, and in this Powell characterises the processes of inorganic, biotic, and an 
thropic evolution as radically distinct. He gives special attention to the distinction between biotic and anthropic evolution, because he regards the prevalent theory that they are identical as one of the most insidious impediments to anthropologic progress. The following extract from the concluding portion of the address includes some of the fundamental elements of his philosophy:

"It has thus been shown that there are three stages in the combination of matter and motion, and that each stage is characterised by a clearly distinct method of evolution. These may be defined as follows :

"First, physical evolution is the result of direct adaptation to environment, under the law that motion is in the direction of least resistance.

"Second, biotic evolution is the result of indirect adaptation to the environment by the survival of the fittest in the struggle for existence.

"Third, anthropic evolution is the result of the exercise of human faculties in activities designed to increase happiness, and through which the environment is adapted to man.

"These may be briefly denominated : evolution by adaptation, evolution by survival of the fittest, and evolution by endeavor.

"Civilised men have always recognised to some extent the laws of human evolution, - that activities are teleologically developed, and that happiness is increased thereby. In the early history of mankind the nature of teleologic endeavor was so strongly impressed upon the mind that the theory was carried far beyond the truth, so that all biotic function and physical motion were interpreted as teleologic activity. When this error was discovered, and the laws of physical and biotic evolution established, vast realms of phenomena were found to have been entirely misunderstood and falsely explained, and teleologic postulates have finally fallen into disrepute. Men say there is progress in the universe by reason of the very laws of nature, and we must let them alone. Thus, reaction from the ancient false philosophy of teleology has carried men beyond the truth, until they have lost faith in all human endeavor; and they teach the doctrine that man can do nothing for himself, that he owes what he is to physical and biotic agencies, and that his interests are committed to powers over which he has no control.

"Such a philosophy is gradually gaining ground among thinkers and writers, and should it prevail to such an extent as to control the actions of mankind, modern civilisation would lapse into a 
condition no whit superior to that of the millions of India, who for many centuries have been buried in the metaphysical speculations of the philosophy of ontology. When a man loses faith in himself, and worships nature, and subjects himself to the government of the laws of physical nature, he lapses into stagnation, where mental and moral miasma is bred. All that makes man superior to the beast is the result of his own endeavor to secure happiness.

"Man, so far as he is superior to the beast, is the master of his own destiny, and not the creature of the environment. $\mathrm{He}$ adapts the natural environment to his wants, and thus creates an environment for himself." 1

The three methods of evolution correspond to a classification of the sciences in three groups: the sciences of matter, the sciences of life, and the science of man as a thinking animal. The individ. ual sciences composing these groups, and their order among themselves, are set forth in an address to the American Association for the Advancement of Science in 1888 .

The essays devoted to the amplification of the outline of human evolution constitute two series. The first series is based upon the recognition of three stages of progress-savagery, barbarism, and civilisation. One address to the Anthropological Society is entitled From Savagery to Barbarism (1885); a second is entitled From Barbarism to Civilisation (1888); a third Evolution in Civilised Man (1887).

"By the division of labor men have become interdependent, so that every man works for some other man. To the extent that culture has progressed-beyond the plane occupied by the brute, man has ceased to work directly for himself and come to work directly for others and indirectly for himself. He struggles directly to benefit others, that he may indirectly but ultimately benefit himself. This principle of political economy is so thoroughly established that it needs no explication here; but it must be fully appreciated before we can thoroughly understand the vast extent to which interdependence has been established. For the glasses which I wear, mines were worked in California, and railroads constructed across the continent to transport the product of those mines to the manufactories in the East. For the bits of steel on the bow, mines were worked in Michigan, smelting-works were erected in Chicago, manufactories built in New Jersey, and railroads constructed to transport the material from one point to the other. Merchanthouses and banking-houses were rendered necessary. Many men

1 Bull. Philosoph. Soc., Washington, Vol. VI., pp. li-lii. 
were employed in producing and bringing that little instrument to me. As I sit in my library to read a book, I open the pages with a paper-cutter, the ivory of which was obtained through the employment of a tribe of African elephant-hunters. The paper on which my book is printed was made of the rags saved by the beggars of Italy. A watchman stands on guard in Hoosac Tunnel that I may some time ride through it in safety. If all the men who have worked for me, directly and indirectly, for the past ten years, and who are now scattered through the four quarters of the earth, were marshaled on the plain outside of the city, organised and equipped for war, I could march to the proudest capital of the world and the armies of Europe could not withstand me. I am the master of all the world. But during all my life I have worked for other men, and thus I am every man's servant; so are we all-servants to many masters and masters of many servants. It is thus that men are gradually becoming organised into one vast bodypolitic, every one is striving to serve his fellow-man and all working for the common welfare. Thus the enmity of man to man is appeased, and men live and labor for one another; individualism is transmuted into socialism, egoism into altruism, and man is lifted above the brute to an immeasurable height. Man inherited the body, instincts, and passions of the brute; the nature thus inherited has survived in his constitution and is exhibited along all the course of his history. Injustice, fraud, and cruelty stain the pathway of culture from the earliest to the latest days. But man has not risen in culture by reason of his brutal nature. His method of evolution has not been the same as that of the lower animals; the evolution of man has been through the evolution of the humanities, the evolution of those things which distinguish him from the brute. The doctrines of evolution which biologists have clearly shown to apply to animals do not apply to man. Man has evolved because he has been emancipated from the cruel laws of brutality." 1

In another place he shows that, though competition of plant with plant and brute with brute is the means of biotic progress, civilised man does not compete with plant or brute, but destroys what are hurtful to him and improves what are beneficial. When man competes with man in the struggle for existence no step in evolution results.

"Vestiges of brutal competition still exist in the highest civilisation, but they are called crimes; and, to prevent this struggle for existence, penal codes are enacted, prisons are built, and gal-

1 Trans. Anthropological Soc, of Washington, Vol. III., pp. 195-196. 
lows are erected. Competition in the struggle for existence is the agency by which progress is secured in plant and animal life, but competition in the struggle for existence among men is crime most degrading. Brute struggles with brute for life, and in the æons of time this struggle has wrought that marvellous transformation which we call the evolution of animals; but man struggles with man for existence, and murder runs riot: no step in human progress is made.

"That struggle for existence between man and man which we have considered and called crime is a struggle of one individual with another. But there is an organised struggle of bodies of men with bodies of men, which is not characterised as murder, but is designated as warfare. Here, then, we have man struggling with man on a large scale, and here it is where some of our modern writers on evolution discover the natural law of selection,- 'the survival of the fittest in the struggle for existence.' The strongest army survives in the grand average of the wars of the world.

"When armies are organised in modern civilisation, the very strongest and best are selected, and the soldiers of the world are gathered from their homes in the prime of manhood and in lusty health. If there is one deformed, if there is one maimed, if there is one weaker of intellect, he is left at home to continue the stock, while the strong and the courageous are selected to be destroyedIn organised warfare the processes of natural selection are reversed: the fittest to live are killed, the fittest to die are pre. served; and in the grand average the weak, physically, mentally, and morally, are selected to become the propagators of the race."1

The second series of essays devoted to the subject of human evolution is based upon the five classes into which human activities are divided and upon the subdivision of these classes. The series is incomplete, but so far as it goes it traverses the ground of the essays of the preceding series, by treating of the evolution of individual activities from their lowest to their highest stages. The essays will be enumerated under their appropriate classes without reference to their order of publication, and it will be convenient to group with them certain papers falling outside the evolutional series but admitting of the same classification by activities.

Within the province of æsthetic arts are two papers. "Esthetology or the Science of Activities Designed to Give Pleasure" (American Anthropologist, 1899) develops a classification of the

I Science, Vol. XI., p. Ir3. 
æsthetic arts and briefly outlines the evolution of each. "Evolution of Music from Dance to Symphony" (A.A.A.S., 1889) traces the development of musical art from its origin with dancing by the successive addition of melody, harmony, and symphony.

In like manner an essay entitled "Technology, or the Science of Industries" (American Anthropologist, I899) classifies the industrial arts, or those activities which conduce to welfare; but the lines of evolution in this field are only briefly indicated.

Under the head of institutions are to be classed four papers, "Kinship and the Tribe," "Kinship and the Clan," "Tribal Marriage Law," and "Sociology or the Science of Institutions."

Tribal society is organised on a basis of kinship, but the system of kinship differs from that of civilisation. In a tribe the line between generations is sharply drawn. Within a generation each man is brother to each other man, and this without reference to degrees of consanguinity. Such distinctions as we make by the word cousin are ignored. The generations stand in lineal order, and each male of one generation is accounted the son of each male of the preceding generation and the father of each male of the following generation. In this fundamental respect tribal kinship differs so widely from the kinship system of our community that it is not easy for us to conceive it; and in other respects it is equally strange. The three essays referred to describe tribal kinship, distinguish its two chief varieties, and explain the kinship system of he clans constituting a tribe, as well as the strange marriage systems which result from and serve to perpetuate the systems of kinship. (Third Ann. Report Bureau of Ethnology, 1883.)

Here also should be mentioned an address on the "Outlines of Sociology" (Anthrop. Soc., I882), in which the State is defined, its evolution is described, and its regulative functions are classified.

Three works fall under the head of language. The first is an "Introduction to the Study of Indian Languages" (1880), and is essentially a code of instructions for the collection of linguistic material. A code of instructions to observers is primarily an enumeration of the particulars as to which information is desired, or as to which it is expected that information can be obtained. These particulars are the categories of existing generalisations on the subject, together with those bearing on existing hypothesis. The full code of instructions for new observation thus embodies the results of all earlier observation, generalisation, and explanation. The language of a people, being invented for the communication of their thoughts, embodies in its vocabulary their arts, their institutions, and their 
philosophy; and an Indian language cannot be profitably studied unless the other activities of the tribe either are understood or are simultaneously studied. And so Powell's Introduction includes under its modest title a succinct compend of the generalisations of North American ethnology.

The second work under this head is an essay on the "Evolution of Language" (First Annual Report Bureau of Ethnology, I88I). Linguistic progress includes very little addition of new material, but consists chiefly of internal change. The processes of change are classed as Combination, or the union of two or more words for a new purpose, Vocal Mutation, Intonation, and Placement or the association of sense relations with the relative positions of words in a sentence. It is shown that the primitive languages differ from the advanced in their imperfect discrimination of parts of speech, in their elaborate inflection, and in their lack of general terms. Progress is through the differentiation of the parts of speech and the substitution of general terms and separable qualifiers for inflected words. "Judged by these criteria, the English stands alone in the highest rank; but as a written language, in the way in which its alphabet is used, the English has but just emerged from a barbaric condition."

The remaining work is an essay on "Philology," which is considered as "the science of activities designed for expression" (American Anthropologist, 1900). The activities are classified as emotional, oral, gestural, written, and logistic languages, logistic language including notations, like the algebraic and musical, in which ideas are expressed directly by signs, without the necessary implication of words. The science of oral language is developed at some length.

Four addresses and essays were devoted to philosophies, or the systems of explanation of the phenomena of nature: the "Philosophy of the North American Indians" was read to the American Geographical Society in 1876 , and "Mythologic Philosophy" to a section of the American Association for the Advancement of Science in I879. The "Lessons of Folklore" and "Sophiology or the Science of Activities Designed to give Instruction" appeared in the American Anthropologist in I 900 and Igor. The first is chiefly descriptive. The second compares mythic explanations with scientific, discusses the successive stages of mythologic philosophy, and indicates the dependence on it of ancientism, spiritism, thaumaturgics, and religion. The third deals with the evolution of philosophies, by pointing out various survivals of primitive explana. 
tions in various classical and modern systems of philosophy. The fourth outlines the evolution of philosophies as an introduction to classification of the ways in which opinions are propagated. Perhaps a fifth paper should be added to this group, an essay on "The Evolution of Religion," contributed to The Monist in 1898 . The following extracts are selected from the first and second essays:

"To fully present to you the condition of savagery, as illustrated in their philosophy, three obstacles appear. After all the years I have spent among the Indians in their mountain villages, I am not certain that I have sufficiently divorced myself from the thoughts and ways of civilisation to properly appreciate their childish beliefs. The second obstacle subsists in your own knowledge of the methods and powers of nature, and the ways of civilised society; and when I attempt to tell you what an Indian thinks, I fear you will never fully forget what you know, and thus you will be led to give too deep a meaning to a savage explanation; or, on the other hand, contrasting an Indian concept with your own, the manifest absurdity will sound to you as an idle tale too simple to deserve mention, or too false to deserve credence. The third difficulty lies in the attempt to put savage thoughts into civilised language; our words are so full of meaning, carry with them so many great thoughts and collateral ideas. In English I say 'wind,' and you think of atmosphere in revolution with the earth, heated at the tropics and cooled at the poles, and set into great currents that are diverted from their courses in passing back and forth from tropical to polar regions; you think of ten thousand complicating conditions by which local currents are produced, and the word suggests all the lore of the Weather Bureau,-that great triumph of American science. But I say neir to a savage, and he thinks of a great monster, a breathing beast beyond the mountains of the west." 1

"There are two grand stages of philosophy,-the mythologic and the scientific. In the first, all phenomena, are explained by analogies derived from subjective human experiences; in the latter, phenomena are explained as orderly successions of events.

"In sublime egotism man first interprets the cosmos as an extension of himself; he classifies the phenomena of the outer world by their analogies with subjective phenomena; his measure of distance is his own pace, his measure of time his own sleep, for he says, 'It is a thousand paces to the great rock,' or 'It is a hundred sleeps to the great feast.' Noises are voices, powers are hands, movements are made afoot. By subjective examination discover-

1 American Geog. Soc. Fournal, Vol. VIII., p. 253. 
ing in himself will and design, and by inductive reason discovering will and design in his fellow men and in animals, he extends the induction to all the cosmos, and there discovers in all things will and design. All phenomena are supposed to be the acts of some one and that some one having will and purpose. In mythologic philosophy the phenomena of the outer physical world are supposed to be the acts of living, willing, designing personages. The simple are compared with and explained by the complex. In scientific philosophy, phenomena are supposed to be children of antecedent phenomena, and so far as science goes with its explanation they are thus interpreted. Man with the subjective phenomena. gathered about him is studied from an objective point of view and the phenomena of subjective life are relegated to the categories established in the classification of the phenomena of the outer world; thus the complex is studied by resolving it into its simple constituents." 1

"In Shoshoni, the rainbow is a beautiful serpent that abrades the firmament of ice to give us snow and rain. In Norse, the rainbow is the bridge Bifrost spanning the space between heaven and earth. In the Iliad, the rainbow is the goddess Iris, the messenger of the King of Olympus. In Hebrew, the rainbow is the witness to a covenant. In science, the rainbow is an analysis of white light into its constituent colors by the refraction of raindrops." 2

Powell's own philosophy, to the formulation of which he devoted several years, is published in Truth and Error, a volume which contains also a treatise on psychology. Had his full plan been carried out, Truth and Error would have been followed by two other books, the second bearing the title Good and Evil. The writing of the second book was completed-the last effective work of his life-and its chapters were printed as independent essays in the American Anthropologist. One of them, "The Categories," pertains to the field of general philosophy; the others have already been mentioned as treatises on human activities.

His only writing devoted largely to intellectual methods is an address to the Biological Society- of Washington at its Darwin Memorial Meeting in 1882 . Three groups of philosophies are here recognised, the mythologic, the metaphysic, and the scientific. It is shown that the method of metaphysics is formal logic, while the method of science consists of induction and hypothesis.

"Now the machine called logic, the tool of the metaphysician, 
is curiously constructed. Its chief hypothesis is that man was primitively endowed with fundamental principles as a basis of reasoning, and that these principles can be formulated. These fundamental principles are supposed to be universal, and to be everywhere accepted by mankind as self-evident propositions of the highest order, and of the broadest generalisation. These fundamental propositions were called major propositions. The machine, in formal logic, was a verbal juxtaposition of propositions with the major propositions at the head, followed by the minor propositions, and from this truth was supposed to flow.

"This formal logic of the Aristotelian epoch has lived from that period to the period of science. Logic is the instrument of metaphysics, and metaphysic philosophy, in its multifarious forms, is the product of logic. But during all that time-2, ooo years-no truth has been discovered, no error has been detected, by the use of the logical machine. Its fundamental assumption is false.

"It has been discovered that man is not endowed with a body of major propositions. It is found that in the course of the evolution of mind minor propositions are discovered first, and major propositions are reached only by the combination of minor propositions; that always in the search for truth the minor proposition comes first, and that no major proposition can ever be accepted until the minor propositions included therein have been demonstrated.

"The error in the metaphysic philosophy was the assumption that the great truths were already known by mankind, and that by the proper use of the logical machine all minor truths could be discovered, and all errors eliminated from philosophy. As metaphysic methods of reasoning were wrong, metaphysic philosophies were false; the body of metaphysic philosophy is a phantasmagoria." 1

Two important essays cannot be included under any of the above classes, as they discuss the material of all. They treat of the methods to be pursued in anthropologic research and the methods to be avoided, of the fruitful lines of inquiry and the barren, of the dangers from the use of superficial observations and of the dangers from faulty principles of interpretation. They are to a certain extent the codification of the counsel by which he has guided the work of his associates in the Bureau of Ethnology, and they are contained in the Annual Reports of the Bureau. One is on "Limitations to the Use of Certain Anthropologic Data," the other on "Activital Similarities."

1 Biolog. Soc. Wash., Proc., Vol. I., p. 63. 
"Here again [in sociology] North America presents a wide and interesting field to the investigator, for it has within its extent many distinct governments, and these governments, so far as investigations have been carried, are found to belong to a type more primitive than any of the feudalities from which the civilised nations of the earth sprang, as shown by concurrently recorded history.

"Yet in this history many facts have been discovered suggesting that feudalities themselves had an origin in something more primitive. In the study of the tribes of the world a multitude of sociologic institutions and customs have been discovered, and in reviewing the history of feudalities it is seen that many of their important elements are survivals from tribal society.

"So important are these discoveries that all human history has to be rewritten, the whole philosophy of history reconstructed. Government does not begin in the ascendency of chieftains through prowess in war, but in the slow specialisation of executive functions from communal associations based on kinship. Deliberative assemblies do not start in councils gathered by chieftains, but councils precede chieftaincies. Law does not begin in contract, but is the development of custom. Land tenure does not begin in grants from the monarch or the feudal lord, but a system of tenure in common by gentes or tribes is developed into a system of tenure in severalty. Evolution in society has not been from militancy to industrialism, but from organisation based on kinship to organisation based on property, and alongside of the specialisations of the industries of peace the arts of war have been specialised.

"So, one by one, the theories of metaphysical writers on sociology are overthrown, and the facts of history are taking their place, and the philosophy of history is being erected out of materials accumulating by objective studies of mankind." 1

The present chapter on Powell's scientific work and the following chapter on his administrative work were written about twelve years ago, at a time when he was at the head of the Geological Survey as well as the Bureau of Ethnology. In preparing them for publication at the present time, the writer has so far revised them that they cover the whole period of his literary' and executive activity. But the following account of his literary style and literary habits, written at the zenith of his activity, is permitted to stand without change of tense or other qualification.

Powell's literary style is influenced in a curious and interesting 
manner by his philosophy. Science does not invent, but discovers; and that which has been discovered needs only to be published in order to become a part of the world's knowledge. It differs in this respect from metaphysics, which postulates its principles and then by the methods of formal logic undertakes to prove its results. In metaphysics demonstration is proving; in science demonstration is merely pointing out. So that all that is absolutely necessary to the presentation of a scientific result is its statement; if the result is worthy of acceptance, it will ultimately be received, for it will be found to accord invariably with the results of new observation. The absolute generality of a conclusion can be established only by comparing it with all the phenomena, and as this is impossible, such comparison as is made serves only to illustrate. The citation of particular instances usually assists the comprehension of a general idea, and illustration is thus a useful adjunct to statement. Powell's philosophical writings thus consist of the statement of results, with a small amount of illustration, and in many instances without illustration. They are for the most part highly concise, and as they often lead the ordinary reader into novel realms of thought, much study is sometimes necessary to their full comprehension. On the other hand, some of his generalisations are so simple as compared to the theories or postulates which they supplant, and are so readily grasped, that they are accepted as axioms and not recognised as the results of laborious research and profound thought.

His style has been further influenced by the loss of his right hand, and by a remarkable power of controlling his attention. The loss of his hand in early manhood led him to depend to an exceptional degree on amanuenses. All of his scientific writings have been dictated to shorthand writers, and escaping thus the delay and the divided attention involved in the personal use of the pen, he has been able to select words with unusual care.

His power to control his attention is exemplified in the daily transaction of business at his official desk. The dictation of a letter or of an essay will be interrupted by a question from a subordinate or by a visitor, and as soon as the temporary business has been transacted the dictation is resumed at the point of leaving off without apparent effort. Through this remarkable power he is able to direct his attention to any selected subject of thought and there concentrate it for an indefinite period. The intellectual labor necessary to the arrangement of a subject for composition is performed without the aid of notes, and the entire subject is elabo- 


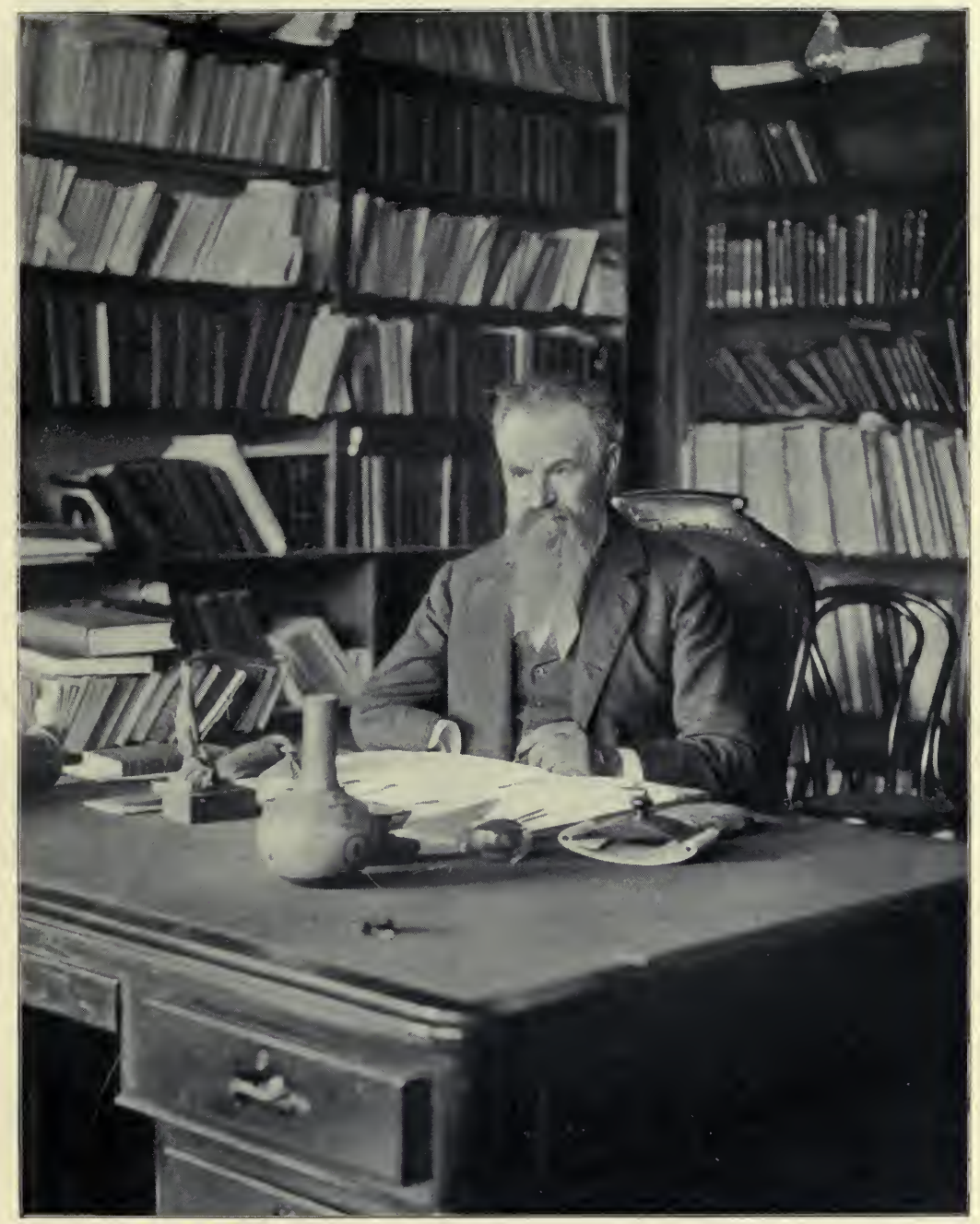

Major Powell in His Office at the Smithsonian Institution. ${ }^{1}$

I After a photograph by Mr. De Lancey Gill. 

rated and stored in the mind before its record is begun. This elaboration extends to the division of the subject into distinct propositions and the arrangement of these propositions in a logical order. It does not ordinarily extend to the framing of sentences, but the ideas to be expressed have passed out of the haze of suggestion in to the clear light of full perception before dictation is attempted. Thus in a second way it results that close attention is given to the selection of words and phrases and the framing of sentences. With many writers the employment of a shorthand amanuensis leads to a diffuse style, characterised by long and involved sentences, but in Powell's case such employment is coincident with a concise style and the prevalence of short sentences,-a difference which I conceive to be due to the fact that his subject is thought out in advance.

During the period of mental elaboration, while the subject is undergoing classification and arrangement, it is often rehearsed to friends in the guise of a topic of conversation; and while it is thus fully at command, it is apt to be drawn on as material for postprandial speeches and other occasional and extempore remarks and especially for discussions in scientific societies. In such ways he tests in advance the reception of the results of his cogitation before committing them even to the private record of the written page. It has occasionally happened that the thoughts thus set afloat have received publication in the writings of others before they appeared in his own. Probably the appropriation has usually been unconscious, but whether so or not the matter is of little moment, for a mind fertile as Powell's need not be a stickler for priority of thought, and the world need not care from what source flow the ideas that constitute its progress.

During dictation his mental activity is correlated with a certain amount of muscular action, as is the case with many authors. Sometimes he sits in a pivoted chair, swinging it one way and another, and accompanying emphatic passages by gesture. "More frequently he paces the floor, with a cigar, lighted or unlighted, in mouth or hand, raising his voice and gesturing with hand and body as though addressing an audience.

Despite the thoroughness of his mental preparation, the manuscript of a scientific article is rarely complete at first writing, but is in that stage criticised in all respects, from its verbiage to its general logic. It is brought under view from time to time for several days, and if possible for several weeks, and is again submitted to friends conversant with the subject for the purpose of eliciting discussion and criticism. 
As a speaker Powell is deliberate and effective. When no manuscript has been prepared, he frames his sentences clearly and completely, and in the style characteristic of his essays. His voice is of moderate strength, but sufficient for the ordinary lyceum audience. Warmed to his subject, his gestures are frequent and withal spontaneous and unconscious. When he speaks in Washington, where he is well known, the audience room is always filled, and he is equally popular on various lecture circuits of the country. In the early years of his governmental work, when he expended his entire appropriation in exploration and drew no salary, he supported himself by lecturing, arranging for a tour whenever his, finances demanded it.

As a debater he is peculiarly ready, not with repartee but with ideas. Indeed the term "debate" ill applies to the discussions in which he ordinarily participates, for these are at the meetings of scientific societies, where the general object is the discovery of truth and not rhetorical victory. His remarks are especially characterised by the originality of their point of view, which usually rises above the special subject and presents some phase of his comprehensive philosophy.

$\mathrm{He}$ often attempts to illustrate what he says by marking with crayon on a blackboard, just as in conversation he frequently marks with pen or pencil on a sheet of paper, but such attempts serve only the purpose of gesture, correlating a certain amount of muscular activity with the mental activity of the moment. The lines he draws rarely bear any relation to the subject.

His hours of labor and hours of recreation and rest have little relation to official hours of business, and he pays small heed to the mandates of the sun. His executive duties indeed require his presence in certain places at certain times, but his scientific work has no fixed time. It recurs to his mind after each interruption, and holds his attention until the next. Recreation in the earlier years of his governmental work was given no regular place, although his life was far from devoid of it. It consisted chiefly of the conversation of friends and family, but included also games. He was fond of whist, euchre, and cribbage, being an expert at the last, and billiards was a favorite entertainment until a disease of the eye impaired his skill. He also drove much, being fond of horses and an expert reinsman, despite the loss of his right hand. These various recreations filled only hours of comparative leisure, and were relinquished for days and even weeks whenever his energies were specially demanded by a crisis of affairs or the formulation of a scien- 
tific subject. Of late years considerations of health have dictated regular exercise, and he has adopted the practice of spending some hours each day in the saddle. Multiplying responsibilities clamor for the remainder of his time, and other recreations are relinquished, unless indeed the social duties incident to his official position be regarded as recreations.

Comparatively few hours are demanded for sleep, and few are given. The hour of retiring is apt to be late, and it is a life-long habit not to linger in bed awake, but to rise on waking whatever the hour. On the other hand, the artificial termination of sleep is not tolerated when it can be avoided. 


\section{THE PROMOTER OF RESEARCH.}

THE preceding chapter outlines the results of Powell's personal 1 investigations as they appear in his published writings. The story would be but half told if no mention were made of the results of his labors as the administrator of scientific trusts. The investigator is apt to be a specialist, concentrating his attention on a single subject to the practical exclusion of all others, and by that specialisation incapacitated for executive work. Powell, however, was eminently a man of affairs. Whether his generalisations and theories were sound and true is a question that may be left to the verdict of posterity, but his contemporaries recognised and declared his eminent ability as an organiser and administrator of scientific work. A multitude of minor responsibilities may be here neglected, but four important trusts must be mentioned, each involving either the direction or the practical guidance of a body of scientific work. The Survey of the Colorado River, which expanded from 1872 to 1879 into the Survey of the Rocky Mountain Region, gradually developed three corps of scientific assistants-a corps of topographers, a corps of geologists, and a corps of ethnologists. The ethnologic work, although but slightly endowed, grew to such importance that in one of the later years of the Survey Professor Henry, Secretary of the Smithsonian Institution, placed at Powell's disposal the accumulated ethnographic material in the archives of the Smithsonian and gave him direction of all ethnographic work carried on in coöperation with the Institution.

When the surveys were reorganised in 1879 the ethnologic work was continued by the constitution of a Bureau of Ethnology, and Powell has been continuously the Director of that Bureau. The Survey of the Rocky Mountain Region published four quarto volumes entitled Contributions to North American Ethnology, and its successor has printed nineteen thick annual reports, four quarto monographs, and twenty-five bulletins. 
In 1879 a few citizens of Washington proposed to organise an archæologic society, and to this end called a meeting of scientific men of the city. Members of the Bureau of Ethnology, foreseeing the growth of Washington as a scientific center and the eventual need of a society whose scope should include not only prehistoric but living man, thought it unfortunate that the ground should be partially occupied by an association restricted to the narrower view, and invoked the aid of their friends to effect a change in the character of the new project. Their endeavor was successful, and the meeting called to organise a society of archæology created instead a society of anthropology. Powell was chosen president, and held the office until 1882 , when he retired temporarily, on account of ill health. He was re-elected in 1884 , and in succeeding years until 1887 , making a total incumbency of seven years.

From I 88 I to 1894 he was also Director of the United States Geological Survey.

Before the direction of ethnologic work fell into Powell's hands the subject already engaged the attention, partial or entire, of a large number of persons throughout the United States. Missionaries among the Indians studied their languages for purposes of communication, and prepared vocabularies. They sometimes made manuscript record also of Indian traditions and mythic stories. Army officers on frontier posts and other persons whose occupations brought them in contact with Indians, were led by curiosity or-by scientific tastes to collect the various articles employed and produced in their arts and to make note of their ceremonies and other customs. The stone implements and shards of pottery so widely scattered over the surface of the land, the mounds of the East and the Pueblo ruins of the West, attracted much attention and were the theme of a fragmentary literature. Here and there a philologist or an ethnologist gave to the subject systematic study, but most of the observation was desultory and of a dillettante rather than scientific character. Since the days of the ethnologist Gallatin the Smithsonian Institution had been a depository for recorded vocabularies of Indian languages and various descriptive manuscripts, and some of these it had published. It was Powell's work to organise this scattered and desultory observation, to give it a systematic plan with definite ends in view, to inform it with scientific method, and to give it a needed stimulus by making provision for the publication of results. The funds granted him by Congress from time to time were not as a rule expended on salaries, although the Bureau has slowly acquired a permanent corps, but were given 
in small grants to scattered workers as a means of increasing their facilities. A large number of persons who were already interested in ethnologic work were provided with the money necessary to meet the expenses of specified undertakings, or payments were made for manuscripts prepared. Others whose occupations afforded them leisure and local opportunity were enlisted in the work and received nominal compensation, not amounting to a salary.

The class of observation to which most attention was given was linguistic. The Introduction to the Study of Indian Languages contained not only a code of instructions but an elaborate set of blanks for the recording of Indian vocabularies; this was widely distributed, and with it went an alphabet specially prepared for the purpose, thus enabling the observers to record in a uniform manner the sounds of Indian tongues, many of which are foreign not only to the English but to all European languages. The work of the permanent assistants of the Bureau has been of two kinds: First, a number of students of special branches, largely linguistic, have been enabled through the funds of the Bureau to devote their entire time to research and to extend their studies to minute details. Second, there have been carried forward works of generalisation and correlation transcending the means of most private individuals and possibly transcending the patience of the unsalaried. One of these is the compilation of a Bibliography of North American Linguistics - the segregation once for all of the references to books required by the students who would monograph the subject of an Indian tongue. Another general work is the classification of linguistic stocks and the compilation of a synonymy or dictionary of all the names that have been used to designate Indian languages or Indian tribes. The number of Indian languages is very large, but certain groups of these are shown, by the existence of many common words or words closely related, to be descendants of the same original tongue. The members of such a group are said to belong to the same linguistic stock, and between two linguistic stocks there are no similarities indicative of common origin. The number of linguistic stocks in North America north of Mexico, now for the first time approximately known, is about sixty.

All of the work of the Bureau was impregnated with the philosophic views of its chief. The work he initiated was carried on by methods of his formulation, and the larger share of the work he fostered and endowed had the continuous benefit of his counsel and suggestion.

The influence of his conversation and informal discussion was 
equally perceptible in the proceedings of the Anthropological Society. Rarely was a paper presented in whose discussion he did not participate; and it was his function, as presiding officer, to point out the bearing of the specific contribution on the larger philosophy of the subject-to assign it its place in the scientific scheme. To him is largely due the tone of the society-the prevailing dignity and earnestness of its proceedings, and the rareness of those laborious records of trivial observations whose discussion has been caricatured in the proceedings of the Pickwick Club. The work of the Society and that of the Bureau are closely related, for the Society is the arena for the discussion of the problems developed in the work of the Bureau; but the Society includes also a large independent membership and discusses a broader range of subjects.

When the Geological Survey was placed in charge of Major Powell, its scientific work was divided chiefly on a geographic basis. A number of geographic districts had been constituted, and each was in charge of a geologist-in-chief who directed all of the work within the district, including general and economic geology, topography, chemistry, etc. Powell made no abrupt change, but he gradually substituted for this a radically different organisation, one in which a geologist versed in a special branch of the subject superintended work only in that department, in which all geographic work was under a single chief of division, in which paleontology had a division by itself, with subdivisions delimited by biotic and geologic lines, in which chemistry, lithology, glacial geology and various other special topics were assigned to corps or individuals, each of whom had the territory of the United States as his field. Geographic lines were still used for the subdivision of the two principal bodies of work, the geography and the general or stratigraphic geology; but in all other respects the kind of work to be done was the basis of organisation.

The Geological Survey is a large government bureau. In most of the bureaus at Washington it is the function of the chiefs to decide questions that arise. The business they transact originates elsewhere, and their action is magisterial or judicial. As chief of the Geological Survey Powell too performed these functions, but he likewise took the initiative to an exceptional extent. Details were arranged by his chiefs of divisions, but the general plans were his, and he was personally conversant with the nature and tendencies of all the work of research. Partly by explicit instructions, 
but to a greater extent by suggestion, he furnished hypotheses to younger men, and thus guided their work.

The financial, clerical, and other accessory work of the Survey was as thoroughly organised as the scientific work, and its business methods contributed greatly to the confidence of legislators in its chief. In his endeavors to secure desired legislation in regard to scientific research he was brought in constant relation with Members of Congress, and their reliance on his judgment and resources was attested by frequent official requests for information on subjects not intimately related to the Survey work. Powell's communications in response to such inquiries and his testimony before committees of investigation constitute a body of literature comparable in bulk with his scientific writings. Though it is the business of Congress to enact only general laws, it is nevertheless its practice to diminish the functions of ill-conducted bureaus and increase the powers of efficient bureau officers. During Powell's administration the field of work of the Geological Survey, at first restricted to the Western Territories, was extended to the entire United States, and the amount of money appropriated for the conduct of its operations was increased from $\$ 150,000$ in 188 I to $\$ 500,000$ in 1894 .

Yet another institution of Washington is partially indebted to Powell for its existence. He was one of the first to suggest and advocate the foundation of a social club for the use of the scientific men, and the preliminary meetings were held at his residence. The reorganisation of western surveys was then in progress, the jealousies of rival factions being at their height, and there were some who held aloof, suspicious of a deep-laid plot. But the club was born, grew, and prospered nevertheless, and by affording Washington scientists an opportunity for frequent intercourse under pleasant auspices, has contributed greatly to the abolition of jealousy and suspicion and the promotion of harmony and coopperation. Washington is as truly the scientific center of the United States as it is the political center, though in a different sense, and the solidarity of its scientific community is of great value as an aid in securing the generous endowment and the wise administration of such departments of research as may legitimately be undertaken by the Government.

It is customary for biographers of scientific men to recite by way of peroration the learned societies to whose offices or mem-. bership they have been elected, the academic degrees conferred on them, and the various testimonials and honors by which their scientific rank has been acknowledged. Powell has not been neg- 
lected in these respects; but as his friend I do not feel it my privilege, as it certainly is not my desire, to do that which would have offended his democratic taste. In his estimation the wearing of medals, decorations, and insignia savored of the creation of an aristocracy of science. And from my standpoint as a biographer a catalogue of honors conferred would belittle my theme. Some men are magnified by titles and diplomas, by medals and ribbons; others do not need them. On Powell's true honor list are the Bureau of 'Ethology, the United States Geological Survey, the baselevel of erosion, and a philosophy of human evolution. 


\section{PERSONAL REMINISCENCES OF ONE OF HIS STAFF.}

IN person the Major, as every one called him, was of medium 1 height and as a young man rather slight. He told me how, at the time of the battle of Shiloh, where he lost his right forearm, his superior officer, General W. H. L. Wallace, a tall and handsome soldier, mounted on a fine large chestnut thoroughbred, seeing him wounded and the enemy closing in, said: "Here, Lieutenant, we're going to be captured in a few minutes; get onto my horse and go back to the landing at once." So saying, General Wallace dismounted, and, strong-armed as he was, picked up this mere boy-lieutenant who might have weighed $125 \mathrm{lbs}$., set him in the saddle and sent him away. It was only a few minutes later that this noble officer received his death-wound. Midst the hissing and singing of bullets and screeching of shells Powell galloped back to the landing, about half a mile distant, the red blood spurting from his wounded arm, and soon arrived white and faint. Thence he was taken off to one of the nearby Union gun-boats where the presence and tender care of his young wife brought the prompt attention to his wound that probably saved his life.

The battle over, he was, with others, sent "up the river" to a hospital, from which after some weeks he returned to his command engaged in the operations about Vicksburg. Some years after the war was over, he applied for a pension. Accordingly his record was examined by the pension officers, who found him not pensionable, as the record showed him to be a deserter [!], having been for some weeks after the battle of Shiloh "absent from his command without leave." This absence covered the time when he was in the hospital. Explanations followed, the proper evidence secured, the record corrected, and the pension granted. This incident, however, permanently affected his views as to the evidence in pension cases and made him lenient toward defects in the rec- 


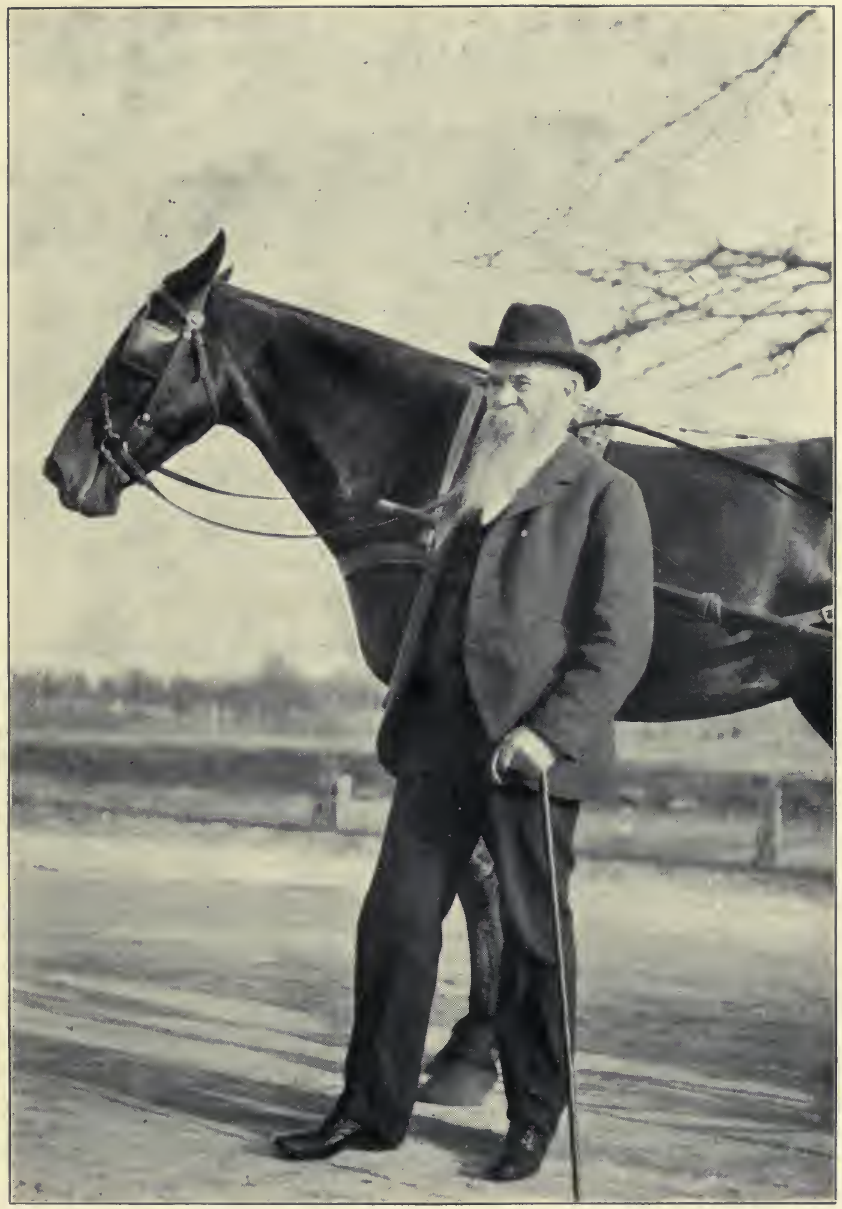

Major Powell with His Horse on an Outing in the Surroundings of Washington, D. C. 

ord. It is so easy, he would say, for a worthy claimant to lack proofs destroyed by war and time. And his sympathetic nature, added to his experience, made him believe that more worthy pension claims were rejected than unworthy ones allowed.

With passing years he grew stouter and heavier. Beside the natural tendency perhaps this was hastened or increased by lack of exercise enforced by the wounded arm, which was tender and frequently painful for so many years. Often in later years prior to the third and last surgical operation, from which complete relief was had, the left hand would almost unconsciously or mechanically take hold of and support the tender stump. Especially was it so if walking or doing anything that gave even a slight jar to the body. So he walked little and rode much. Always fond of horses, he did much riding in buggy and saddle up to the last few years. When engaged in his western surveys, he was loath to let the driver drive, preferring himself to mount the box and with his one hand manage the four-horse team over the rough and trackless regions where his work lay. An early riser, he often had his party on the road at or before daylight, and his early rising habit continued to the end.

In appearance, as we saw him from day to day in the high noon and afternoon of his busy life, he was of medium height, rather stout, deliberate in speech and action, with long full brown beard, prominent eyebrows, deep-set half-closed eyes that had a merry twinkle in them, a noble forehead and loose unkempt hair brushed back and never parted ; in manner dignified, affable, courteous; in dress careless but not slovenly. In his soft felt hat, he seemed too much absorbed in his work and philosophy to think of his dress. A constant smoker, he seemed never conscious of the cigar's presence but only of its absence.

It was in the full activity of his middle life that I first met him, when the newly created United States Geological Survey was young and when organisation, methods, plans, policy, and administration were live and burning questions. Into these he plunged with a zeal and an energy that were infectious and which inspired in his associates perfect confidence and a loyal and devoted following. In those days, and particularly during the Congressional investigation of the Hydrographic Office, Weather Bureau, Coast Survey, and Geological Survey in $1885-1886$, large drafts were made on the time, strength, and energies of his-I will not say subordinates, though such they were, but rather upon his-associates and companions, for such he always made them. But no amount of work 
by any of his comrades could equal that of their leader, whose capacity for work seemed unlimited. Nights, Sundays, holidays were forgotten in the zeal to do the many things that pressed in upon the man who had a reputation for doing things. In the midst of it all, however, his door was always open. He did not appear to hurry, however swift the work in hand went forward, and never showed irritation at the ceaseless interruption entailed by being readily accessible to all comers. He was in this respect like our martyr-president Lincoln who, when the furrows were deepening in his face as the great war wore on, and his faithful helpers sought to persuade him to deny himself to a part of the great throng that sought for interviews, listened kindly and then said as his face lighted up: "They don't want much and they don't get much; I guess I'd better see them." This was the spirit that always prevailed about "the Major's" busy office.

In a high degree Major Powell had the faculty of stimulating his followers and helping them to accomplish the best that was in them. His directions never appeared to be orders. He seemed to be a companion discussing and suggesting plans rather than a director prescribing a course of action, and this practice to those accustomed to different conditions was most stimulating.

He was ever prone to draw from his associates their views and then in a few sentences to lead them to broader ones and to kindle enthusiasm for these wider views. Great as was his personal work, yet much greater was that which owed its inception to his own fruitful suggestion. He rarely printed anything without first submitting it to one or several of his associates for criticism, both destructive and constructive. "Now go for it," he would say, and sometimes add with a twinkle under his shaggy brows, "or ever after hold your peace." The usual outcome of such criticism was not a change of view but rather the reply, "I see I have not made that plain; I must expand it."

If the Major engaged in reminiscence, as he sometimes did, there was often a deeper purpose than mere story-telling or entertainment. There was a principle or a lesson involved, but it was never obtrusive. On one occasion when dining at my house he met a newly appointed Chief of Bureau, one new to Washington and its methods. The conversation turning on administration, he outlined in a few clear, terse sentences the characteristics and methods of five secretaries under whom he had served. "One," said he, "cleared up his table every night, and so made mistakes. Another carefully weighed everything brought to him, and thus was over- 
whelmed with details and business impeded;" and so on of others. "But as to one," said he, "the best of all, he met all matters brought to him by his bureau chiefs with the same question, viz., "Is that a bureau question or a department question?" If it was a department question, he gave to it his undivided attention and profound study. Then he decided and his decisions were right; they have withstood the tests of experience and are the rules of the Department to this day."

More and more, as time passed, his interests and thoughts turned toward philosophical reflection and study, and when his chief burden of administration was laid down in 1894 and the care of the Geological Survey was turned over to another, he entered upon the closing chapter of his varied and busy life.

It was about this time that some of his intimate friends arranged to have a bust made of him. Mr. U. S. J. Dunbar had at this time a studio in the Corcoran Building, and here Powell gave sittings to this artist who in the course of a few weeks produced a clay bust which was generally approved as a faithful and satisfactory portrayal. Later a new bust was cast in bronze and is now in the Library of the United States Geological Survey.

During the sittings I was always with him and generally read aloud from something he liked. One thing read was Ruskin's Essays, and as the reading proceeded he would interpret, analyse, and criticise, pointing out the author's strength, weakness, and limitations. Poetry also interested him, and we read Tam O'Shanter, which he knew by heart.

Such were the traits of this strong and noble character as they appeared to one who for a decade was very near to and in confidential relations with him. I count it one of my pieces of special good fortune to have so long enjoyed the intimate friendship of so helpful, so stimulating, so ennobling a companion as Major John Wesley Powell. 


\section{THE CHIEF.}

M AJOR John Wesley Powell received honoris causa the doctor's I degree of the University of Heidelberg, which is a rare distinction ranging high above the title of doctor that is conferred to applicants on the ground of a thesis and a due examination called the rigororum. The doctor's degree honoris causa is given only to men of extraordinary merit when they have acquired sufficient fame no longer to be in need of titles. The philosophical faculty of Heidelberg so correctly and pointedly stated the reason for conferring the honorary degree of doctor upon Major Powell, that we here reproduce an English translation of that portion of his diploma. It reads as follows:

"We, the Senior Dean and other professors of the Faculty of Philosophy in the Karl Rupert University, duly certify by this diploma bearing our seal that we have conferred the rights and privileges of a doctor of philosophy, honoris causa, upon that most learned and distinguished man, John W. Powell, of Illinois, heretofore chief of the public institution of ethnography, now of geology, in the United States of America, who laboriously and wisely studying and measuring the vast and spacious regions of his own country with others, has scientifically observed and expounded the structure, form, and origin of the earth; and who has so associated with himself and brought together into one institution a great number of the most distinguished geologists of his country that they have materially advanced or solved, not less wonderfully than speedily, very difficult and profound questions in mineralogy, petrography, geology, and paleontology; they have studied under his auspices as chief, thereby causing these things not only to be most skilfully brought together in various works, but also to be communicated with the greatest liberality, to all students of these subjects in Europe."

Major Powell was not only a scientist but also a chief; he was 
an organiser, and it is his spirit even to-day after he has passed away that pervades the institutions which with him and partly through him were called into existence. Yet while he was a born leader, he was never domineering but always amiable and considerate. He appeared to the younger generation that grew up under the influence of his powerful personality, not as their teacher or master, but their senior friend, and they in their turn learned to look up to him with love and confidence as to a father or elder brother. 




